\title{
An Empirical Analysis of the Seasonal Patterns in Aggregate Directors' Trades
}

\author{
Basel Nassar ${ }^{1}$, Mahir Arzoky ${ }^{2}$, Ali Tarhini ${ }^{2} \&$ Takwa Tarhini $^{3}$ \\ ${ }^{1}$ Department of Economics and Finance, Brunel University London, Middlesex, UK \\ ${ }^{2}$ Department of Information Systems and Computing, Brunel University London, Middlesex, UK \\ ${ }^{3}$ Department of Electrical and Computer Engineering, University Texas A\&M, Qatar \\ Correspondence: Mahir Arzoky, Department of Information Systems and Computing, Brunel University London, \\ Middlesex, UB8 3PH, UK. Tel: 44-798-092-6555. E-mail: arzoky@gmail.com
}

Received: June 2, 2015

doi:10.5539/ijef.v7n9p59
Accepted: June 24, 2015

Online Published: August 25, 2015

\begin{abstract}
This paper examins the seasonal patterns in aggregate insider trading transactions, specifically, do insiders prefer to trade on any particular day of the week or month of the year? It also, given that such seasonal patterns exist, attempts to relate these patterns to explanations drawn from the literature on calendar anomalies in returns (and volumes). The results outlined from this paper includes: There is a day of the week anomaly in aggregate insider activities (as measured by number and value of insider transactions). Particularly, relative to other days, insiders tend to trade more on Fridays and less on Tuesdays. Also, the distribution of the average value of directors' trades (buys and sells) across the week days forms a U shape i.e. high trading value on the beginning of the week (Monday) and the end of the week (Friday). Also, there is a month of the year anomaly in aggregate insider activities (as measured by the number of insider transactions). Insiders tend to trade most frequently in March and least in August. The results of OLS Regression Model indicate that there is no monthly anomaly in aggregate insider selling activities as measured by the aggregate value of insider transactions. The results of TOBIT Regression Model show that the average value of directors' selling activities in March is higher and significantly different relative to other months of the year. The results of OLS regression are also confirmed by the results of $\mathrm{K}-\mathrm{W}$ statistic test which supported the non existence of monthly anomaly in aggregate director trading (measured by the value of director transactions).
\end{abstract}

Keywords: director trading, informativeness, patterns, industry classification

\section{Introduction}

The efficient market hypothesis (EMH) suggests that at any given time, prices fully reflect all available information on a particular stock market. The weak form of the market efficiency hypothesis suggests that the current price fully incorporates all the information contained in the record of past share prices. Thus, no investor can gain an advantage in predicting the return on a stock using past price observations. The empirical literature in this area is vast. For example, a number of seasonality or calendar anomalies in equity trading, such as the Day-of-the Week, Month-of-the Year, or turn of the year (January effect), amongst others, have challenged the weak form of the EMH. The existence of these anomalies may indicate market inefficiency, which in turn provides a possibility for market participants to gain abnormal returns by creating a set of trading rules.

Two of the most documented anomalies in equity markets are the day of the week effect (also known as Monday effect) and turn of the year effect (known as the January effect). The Monday effect occurs when returns are lower, or negative, on Monday in comparison with returns on other days of the week. The January effect is another common anomaly that is inconsistent with the EMH. This calendar effect happens when certain stocks generate higher returns in January compared to other months of the year.

One aim of this study is to specifically test for seasonal patterns in aggregate insider trading transactions (as measured by the aggregate insider number and value of insider transactions). Specifically, do insiders prefer to trade on any particular day of the week or month of the year? The literature in this paper attempts to simply identify whether these anomalies exist and/or to try to explain their existence. For example, Cross (1973) and French (1980) reported negative returns on Monday. This may be due to the methodology employed or the way 
of calculating returns (Connolly, 1989), investor psychology (Rystrom \& Benson, 1989), the difference in trading patterns of individual and institutional investors (Lakonishok \& Maberly, 1990), or settlement procedures (Keef \& McGuinness, 2001).

The day of the week anomalies in trading volume has also been examined by Lakonishok and Maberly (1990) and Sias and Starks (1995) with the aim of explaining calendar anomalies in stock returns. These studies suggested that Monday trading volume is higher compared to other days of the week. More specifically, there are more tendencies to sell on Mondays than to buy for individual investors or more tendencies to buy than to sell for institutional investors (Lakonishok \& Maberly, 1990). The reason for this anomaly, as given by these studies, is related to the private information hypothesis and the behaviour of individual and institutional investors. To the best of our knowledge, no examination of the day of the week effects in aggregate insider activities as measured by the aggregate number of directors' trades has yet been carried out.

Similarly, studies by Rozeff and Kinney (1976), Keim (1983) and Gu (2003) documented positive returns on January. The existence of this anomaly can be explained by a tax loss selling hypothesis (Fountas and Segredakis, 2002), window dressing hypothesis (Haugen \& Lakonishok, 1987), new information provided by the firms at the end of the financial year (Barry \& Brown, 1984), or insider trading activities (Seyhun, 1988b, and Hillier \& Marshall, 2002a).

Trading volume anomalies in aggregate insider activities was also examined by Seyhun (1988b) and Hillier and Marshall (2002a). Seyhun (1988b) examined the monthly pattern of aggregate insider transactions in the US over the period 1975-1981with the aim of testing two competing explanations of the January effect the price pressure hypothesis (This hypothesis states that the large positive return at the turn of the year arises due to price pressure from predictable: seasonal changes in the demand for different securities) and the risk premium hypothesis (This hypothesis states that the large positive returns in January observed among small firms compensate for the increased risk of trading against informed traders). The results indicated that some insiders tend to accelerate their planned stock purchases and postpone their stock sales in December. Therefore, this enables insiders to capture a return that is more positive in January. Also, using aggregate insider trading, Hillier and Marshall (2002a) examined the January effect in UK securities and found that it was significant, but not persistent through time. Furthermore, the results showed that the seasonality in insider trading was not the main determinant of the turn of the year effect. Both of these studies used the aggregate number of insider trades as their measure of insider trading activity. Hillier and Marshall (2002a) used only six years insider trading data. We re-examined this in the UK by using a much longer time period (20 years), which may allow us to test for the persistence of this effect. Furthermore, we introduced another measure of insider trading activities, namely, the aggregate value of directors' trades. To the best of our knowledge, the day of the week effect in aggregate insider trading activity has not been examined yet.

A second aim of this paper, given that such seasonal patterns exist, is to attempt to relate these patterns to explanations drawn from the literature on calendar anomalies (in returns and volumes).

Although the purpose of this paper is purely to identify whether such anomalies exist, we do not attempt to explain why they do. We suggest this is an avenue for further research in this area.

The paper is organised as follows. Section 2 reviews previous studies on stock market anomalies and the explanations provided for both daily and monthly patterns in these anomalies. Section 3 sets the hypotheses. Sections 4 and 5 present the data and methodology. Section 6 discusses the results while Section 7 presents the conclusions.

\section{Background}

This section reviews the literature which identifies whether calender anomalies on returns (and volumes) exist and/or tries to explain their existence. More specifically, Section 2.1 reviews the literature which identify whether day of the week anomalies exist and/or tries to explain their existence, whereas Section 2.2 reviews the literature which identifies whether month of the year anomalies exist and/or tries to explain their existence. Section 2.3 reviews the existence literature of calendar anomalies in trading volume which aims of explaining stock returns anomalies. This literature will help us, later, setting our hypotheses in Section 3.

\subsection{Day of the Week Effects in Returns}

The day of the week anomaly (known as Monday effect) refers to the tendency of stocks to exhibit relatively negative returns on Mondays compared to other days of the week. This section reviews the studies which identified the existence of the day of the week anomalies and/or studies which try to explain their existence.

When examining US markets, Cross (1973), French (1980), Gibbons and Hess (1981), Keim and Stambaugh 
(1984), Lakonishok and Smidt (1988), Bessembinder and Hertzel (1993) and Siegel (1998) reported significantly negative mean return on Mondays and high mean returns at the end of the week (Friday).

Using data collected from the US, Canada, and the UK stock markets, Jaffe and Westerfield (1985 a, b) reported negative returns on Mondays, whereas the data collected from Japanese and Australian stock markets showed negative returns on Tuesdays. In Paris Stock Exchange, Solnik and Bousquer (1990) reported similar strong and negative returns on Tuesday. Agrawal and Tandon (1994) examined the seasonality patterns in stock returns considering eighteen countries other than the US such as Australia, Belgium, Brazil, Canada, Denmark, France, Germany, Hong Kong, Italy, Japan, Luxembourg, Mexico, the Netherlands, New Zealand, Singapore, Sweden, Switzerland, and the UK and found lower (or negative) mean returns on Mondays and Tuesdays and higher (and positive) returns from Wednesdays to Fridays in almost all of these countries. Additionally, Arsad and Coutts (1997), Mehdian and Perry (2001), and Gregoriou, Kontonikas and Tsitsianis, (2004) examined the day of the week effect in the UK and found negative Monday returns.

Also, when examining emerging markets, Aggarwal and Rivoli (1989) and Wong et al. (1992) noticed lower mean stock returns on Mondays and Tuesdays in Hong Kong, Singapore, Malaysia, Thailand and the Philippines. Balaban (1995, 1996) and Dicle and Hassan (2007) found that the lowest, and negative, mean returns were on Tuesdays, and the highest returns and the lowest standard deviations were on Fridays in Turkish stock market. Martikainen and Puttonen (1996) reported negative and statistically significant average return on Tuesdays and Wednesdays in Finnish stock market. This pattern was repeated in studies by Elango and Al Macki (2008) and Hussain et al. (2011) for Indian Stock Exchange, whereas Ajayi et al. (2004) analysed the calendar behaviour of Vietnamese, Estonia and Lithuania stock market respectively and confirmed the same pattern (i.e. negative average returns on Tuesday).

These studies, however, contradicted the presence of Day of the Week anomalies in stock market returns.

Another strand of literature tried to explain these seasonal patterns by examining various hypotheses such as calendar time hypothesis, trading time hypothesis, and time zone hypothesis. According to calendar time hypothesis, Monday's average return is three times higher than other days' average returns. This is because Monday's average return is estimated from the closing price on Friday until the closing price on Monday. (French, 1980). On the other hand, Trading Time Hypothesis states that all days average return (Monday through Friday) should be the same because each day's return represents one day's investment (Draper \& Paudyal) whereas Time Zone Hypothesis states that Tuesday's effect is due to time difference between US market and other markets (Jaffe \& Westerfield, 1985; and Condoyanni, O'Hanlon, \& Ward, 1987).

Other studies (e.g., Connolly, 1989; Sullivan, Timmerman, and White 2001; Hansen, Lunde and Nason, 2005) assumed that the day of the week effect might be a result of used methodology of estimation and testing. Investor's psychology is, as well, viewed as a cause of Day of the Week anomalies (Rystrom \& Benson, 1989). Specifically, investors would be more likely to sell (buy) more stocks on Monday (Friday) if they felt pessimistic (optimistic) and, therefore, create downward (upward ) pressure in prices. Similarly, Nath and Dalvi (2004) suggested that investors avoid trading against informed traders on Mondays who might have more information received during the weekend. Thus, investors would likely to buy less on Monday.

Based on these priors, one aim of this paper is to examine the presence of Day of the Week effect in insider trading activities as measured by aggregate number and value of insiders' trades.

\subsection{Month of the Year Effects in Returns}

The month-of-the-year effect is a calendar anomaly according to which stock returns show a rise or fall during certain months as compared to the mean. These seasonal effects are modelled using time series data and tend to be repeated every calendar year. Month of the year is also called January effect; this is particularly due to the tendency of stocks to perform better in January compared to any other time of the year (Rozeff \& Kenney, 1976). This section reviews the studies which identified the existence of the month of the year anomaly and/or studies which try to explain their existence.

Using different US indices, Rozeff and Kinney (1976), Lakonishok and Smidt (1988) and Mehdian and Perry (2002) found that the mean January return is higher than mean return of other months. Similarly, but using UK data, Reinganum and Shapiro (1987), Arsad and Coutts (1997) and Hillier and Marshall (2002a) showed significantly positive returns in January for the entire period under examination and positive returns also in the months of April and December.

January effect is also conducted by Choudhry (2001) and Gu (2003) using data from the pre-World War I era for the US, UK, and Germany, Canada, France, and Japan. 
Empirical literature on stock return anomalies provided many explanations to the turn of the year effect (the January effect). Among these explanations are tax loss selling, capital gains taxation, and new information release hypotheses.

Tax loss selling hypothesis is the most frequent explanation to the turn of the year anomalies. According to this hypothesis, investors, in order to avoid taxes on capital gains, realise capital losses to offset capital gains by selling losers stocks in December. This would cause high selling pressure in December which is relieved in January bringing about large capital gains for losers (Fountas \& Segredakis, 2002; and Chen \& Singal, 2004).

Another related explanation is called capital gains taxation hypothesis. This hypothesis states that if investors realise capital losses to offset capital gains, it is also possible to delay capital gains realisation, so that they can delay tax payment on capital gains. By doing so, investors might postpone tax payment by one year. Thus, investors would sell winners (shares) in January. Hence, the selling pressure in December would be small causing the price to rise.

Both of these hypotheses are based on tax purposes .i.e. investors, in order to avoid taxation, sell more in December or delay selling to January causing an increase in January returns.

Studies by Roll (1983), Reiganum (1983) and Brown et al. (1983) suggested that tax loss selling hypothesis is the main driver of high January returns. These studies focused on small firms where price variation is high compared to other firm sizes (medium or large).

Additional evidence for the tax-loss hypothesis in countries such as UK and Australia with a tax year-end other than the end of December has been also provided by many studies. For example, Brown, Kleidon and Marsh, (1983) reported July effect in Australia following a June tax year end. Reinganum and Shapiro (1987), Arsad and Coutts (1997), Draper and Paudyal (1997), and Baker and Limmack (1998) reported April effect in UK following 5th of April tax year end for individuals. These studies concluded that January (and April) anomaly may be due in part to a tax-loss-selling hypothesis.

Constantinides (1984) and Chen and Singal (2004) suggested that rational investors should realise long-term capital gains to re-establish a short-term status to make short-term capital losses in the future. Moreover, investors should sell losers in December to realise capital losses and sell winners in December to re-establish a short-term status. Rozeff and Kinney (1976) provided another explanation to January anomalies, which is the information release hypothesis. This hypothesis states that January effect is caused by the information released by the company at the end of the financial year. The release of information in 1st of January creates and then resolves uncertainty and lead to (temporary) risk. Penman (1987) hypothesised that firms release good news in the beginning of each quarter and delay the releasing of bad news until the second half of the quarter. Thus, if the market reacts automatically to the news, stocks should earn higher returns in the first few days of each quarter. Also, Brennan and Subrahmanyam (1995) suggested that stocks with high information suffer less compared to stocks with poor information. That is to say, if the information hypothesis is true, the January effect should relate negatively to the number of analysts forecasts. Hence, the smaller the number of analysts' forecasts, the greater the January returns.

Based on these priors, another aim of this paper is to examine the presence of Month of the Year effect in insider trading activities as measured by aggregate number and value of insiders' trades.

\subsection{Calendar Anomalies in Trading Volume}

The purpose of this section is to review the literature on calendar anomalies in trading volume in order to provide a rationale to our research. Lakonishok and Maberly (1990) provided another reason for the negative Monday returns. They argued that the difference in trading patterns of individual and institutional investors (This study differentiates between institutional and individual investors based on trade size. Moreover, large stocks are mostly be held by institutional investors, whereas small stocks are likely to be held by individual investors) is one of the driving forces behind the negative Monday returns. They documented low trading volume on Monday for institutional investors and the opposite pattern for individual investors (.i.e. high trading volume on Monday). For buy and sell transactions, the increase in individuals activity on Mondays is not symmetric. Hence, individuals tend to sell more than to buy on Monday which, partially, might explain weekend effect. Osborne (1962) predicted that, individual investors spend more time on financial decisions during the weekend, whereas institutional investors are less active in the market on Monday because Monday tends to be a day of strategic planning. Therefore, individual investors are relatively more active in the market on Monday. Another reason why individual investors tend to sell more at the beginning of the week than to buy is that individual investors might decide to not engages in a buy transaction before his or her sell transactions are executed. Similarly, 
Abraham and Ikenberry (1994) studied the trading patterns of individual investors and supported the results of Lakonishok and Maberly (1990) that individual investors tend to sell more on Mondays. Based on the hypothesis that private information is received throughout the week while public information is received only on working days, informed trader might have more information on Monday than on other days of the week (Sias and Starks, 1995). Hence, more informed trading would occur on Monday than on other days of the week leading liquidity trades to avoid Mondays.

Furthermore, without public information, informed traders carry information from Monday to other days, so that price sensitivity is the same each day (to the order flow). The presence of public information reduces the effects of private information. Thus, more information is released through trading early in the week (Monday) because price sensitivity to the order flow would be low. In the presence of liquidity traders, the concentration of the trading is going to be on two days each week (Monday and Friday). This is the case when there are high public information signals. When public information signals are poor, liquidity traders would concentrate their trading on Friday. In this case, the trading volume by liquidity and informed traders might form a U-Shape. The U-Shape in intraday and interday trading volume patterns was previously found by Foster and Viswanathan (1990), Jain and Joh (1986), and Admati and Pfleiderer (1988). These studies showed high trading volume on Monday and Friday (Foster \& Viswanathan, 1990) and in the first and the last hours of the trading day (Admati \& Pfleiderer, 1988). Similarly, Blau, Van Ness and Van Ness, (2009) documented that the U-shaped pattern in intraday returns is caused by large trades because changeling in prices from larger (smaller) trades are higher (lower) at the beginning and end of the day. This is attributed to the fact that smaller trades, in periods of low volume, would move prices because informed traders do not want to reveal their information to the market. When volume is high, informed traders are able to increase the size of their trades because their information would be hidden by high volume.

Badhani (2006) analysed the intraweek trading patterns of Foreign Institutional Investors in India and found low buying and selling volumes on Tuesdays. This Tuesday-effect may be a reflection of Monday-effect on institutional investors trading activities documented in US.

Turning to monthly anomalies, the window dressing hypothesis offers another explanation of the January effect. According to this hypothesis which is developed by Haugen and Lakonishok (1987) and Lakonishok et al. (1991), institutional managers' performance and investment philosophy are used to evaluate them. To improve their performance, the institutions buy both risky and small stocks but sell them before the year ends. Therefore, their year-end holdings will not show these stocks. In January, investment managers replace winners, large, and low risk stocks with losers, small and risky stocks.

Musto (1997) examined the window-dressing among money market instruments and found a January effect among those instruments that do not generate capital losses. He concluded that window-dressing activities of the institutional investors could explain the January effect at least partially. Similarly, Ritter and Chopra (1989) and Meier and Schaumburg (2004) provided supporting evidence for the window-dressing hypothesis. On the other hand, Sias and Starks (1997) evaluated the tax-loss-selling and the window-dressing hypotheses by looking at transaction data for stocks dominated by institutional investors versus those dominated by individual investors. Although they found that institutions tend to buy recent winners, which is consistent with the window-dressing hypothesis, they did not find any evidence of institutions selling losers, and their data did not show whether the winner buying institutions have year-end disclosures. Chen and Singal (2004) found no evidence for the window-dressing hypothesis by examining the stocks' return and volume patterns at the end of the semi-annual period (June-July) when tax-loss-selling is not expected.

Lower volume of sales tends to be associated with losers (stocks, the prices of which have decreased) on December because investors, by postponing their sales by a month or two, postpone payments of capital tax by a full year. On the other side, the volume of sales for winners stocks tends to be higher on December because investors would apply these losses against their taxable incomes soon as possible (Dyl, 1977; and Henderson, 1990). Lakonishock and Smidt (1986) assumed that there is a positive correlation between price and trading volume. Moreover, if the trading volume is affected by the degree of attention the company received, thus companies with large increase (decrease) in price might experience increase (decrease) in trading volume. Based on that, investors, who believe that price and trading volume are positively correlated, may be attracted by winners stocks and avoid losers ones.

Seyhun (1988b) tried to relate January effects with insider trading activities by examining two competing hypotheses; price pressure and risk premium hypotheses. More specifically, the increase in insiders buying activities in December as a response to January's positive returns would enable insiders to capture price increase 
in January. Hence, price pressure hypothesis assume insiders in small firms to be net buyers in December (the opposite pattern can be observed for insiders in large firms). On the other hand, risk premium hypothesis assume high buying or selling activities by insiders in january. However, the results showed that insiders buy more and delay selling shares in December to benefit from price running up in January. In contrast to the US studies, Hillier and Marshall (2002a) examined the January effect in the UK listed securities and found that it was significant but not persistent through the time. Moreover, the results showed that seasonalities in insider trading were not the main determinant of the turn of the year effect.

\subsection{Summary}

To summarise, previous empirical literature in stock returns anomalies supports the existence of the day of the week effect i.e. negative returns in the beginning of the week and high returns at the end of the week. These anomalies might be driven by the methodology employed or the way of calculating returns, investor psychology, the difference in trading patterns of individual and institutional investors, or settlement procedures. Also, the literature on trading volume suggests that Monday's trading volume is higher compared to other days of the week. More specifically, investors sell more on Monday if they are individual investors and sell less if they are institutional investors. This is perhaps due to the private information hypothesis and the behaviour of individual and institutional investors. Similarly, previous empirical literature in stock returns anomalies supports the existence of the month of the year effect i.e. high returns on January. These anomalies might be driven by the tax loss selling hypothesis, window dressing hypothesis, or new information provided by the firms at the end of the financial year. Also, the turn of the year effect might be due to director trading activities as measured by the aggregate number of directors' trades (Seyhun, 1988b, and Hillier \& Marshall, 2002a).

The first aim of this paper is to specially test for seasonal patterns in aggregate insider trading transactions (as measured by the aggregate insider number of trades and the aggregate value of insider transactions). Specifically, do insiders prefer to trade on any particular day of the week or month of the year? Secondly, given that such seasonal patterns exist, we are going to attempt to relate these patterns to explanations drawn from the literature on calendar anomalies in returns (and trading volume).

\section{Hypotheses}

The previous literature on the day of the week and month of the year anomalies in stock returns has attempted to identify whether these anomalies exists and/or to try to explain their existence. We examine the existence of the day of the week and month of the year anomalies in aggregate director trading activities as measured by the aggregate number and value of insider transactions. We commence by examining whether insiders have more preference for trading in any particular day of the week. In other words, we test the following hypothesis;

Hypothesis (1): There is no day of the week effect in aggregate insider activities as measured by the aggregate number and value of directors' trades

Sias and Starks (1995) suggested that more informed investors tend to trade on Mondays than other days of the week because private information is available all days of the week including weekends while public information are only available on working days. Given that insider trading literature is ambiguous and suggests that informed trades are likely to be buy trades, we might expect;

Hypothesis (2): The aggregate volume of directors' buy (sell) trades is higher (lower) on Monday than on other days of the week.

Focusing on the turn of the month, we first examine simple whether directors have preferences to trade at any particular month of the year. Therefore;

Hypothesis (3): There is no month of the year effect in aggregate insider activities as measured by the aggregate number and value of directors' trades

In the UK, the tax year for the firms corresponds to the calendar year, whereas the tax year for the individuals ends at 5th of April. The tax loss selling literature, which is often used as an explanation for the turn of the year anomaly, suggests that firms and individuals sell more in the month before the end of the year and buy more after (Seyhun, 1988b; Hillier \& Marshal, 2002a; and Chen, Jack, \& Woods, 2007). Tax loss selling hypothesis states that investors sell stocks that have declined in value in December/March (one month before the taxation date) to realise capital loss and offset it against capital gain tax. In January, the stocks that have been sold would recover resulting high returns in January/April. Thus, our fourth hypothesis is:

Hypothesis (4): Directors tend to sell more in March and buy more in April compared to other months of the year 


\section{Data}

This study is based on data collected between January 1991 and December 2010 by two different data sources,

1) Directus Ltd compiled a complete record of director's trades in the United Kingdom (1991-2001).

2) Directors Deals, which monitors and analyses share transactions made by directors in their own companies (sometimes known as Insider Deals).

The original dataset provides information on various transaction types, but we removed trades other than open market purchases and sales of ordinary shares by directors. We removed trades such as option exercise, derivative, script dividends or bonus shares, rights issue, awards made to directors under Incentive plans or reinvestment plans, gifts, transfers and purchase, and sales of shares under personal equity plans, operations derived from tax or "bed \& breakfast". Open market sales and purchases are more likely to represent actions taken because of special insider information (Seyhun, 1988a; Gregory et al., 1994; and Friederich et al., 2002).

This period yields a sample of 91,970 trades for every publicly disclosed transaction by UK directors in their own firms.

\section{Methods}

This study uses daily values (and numbers) of directors' trades from 1 January 1991 to 31 December 2010. Using daily data allows us to examine the relationship between the changes of trades' value (number of trades) from one trading day to the other. In order to avoid possible bias of missing information due to public holidays, five observations per week were used.

The linear regression model and the ordinary least squares-method (OLS) were employed. Brooks (2014) suggested several assumptions for the classical linear regression model. They included for example homoscedasticity of the residuals and zero autocorrelation among residuals. We decided to use the OLS method because it has been used largely in anomalies testing. For example, Gibbons and Hess (1981) and Ajayi, Mehdian and Perry (2004) used this method while Brooks (2014) suggested that this is the basic method for studying calendar anomalies.

Classical assumptions are necessary for the OLS to be the best linear estimation method for the regression model.

Our sample contains transactions whose values are more than $£ 15$ million and transactions whose values are $£ 1$ or less. These transactions might (or might not) have an impact on our results. Thus, to examine whether these observations have an influence on regression estimates, we run the OLS regression and test for the heteroscedacity of residuals.

Formally, we used the following regression model:

$$
\begin{gathered}
\text { Value }_{t}=\beta_{\text {Monday }} D_{\text {Monday }}+\beta_{\text {Tuesday }} D_{\text {Tuesday }}+\beta_{\text {Wednesday }} D_{\text {Wednesday }}+\beta_{\text {Thursday }} D_{\text {Thursday }}+ \\
\beta_{\text {Friday }} D_{\text {Friday }}+e_{t}
\end{gathered}
$$

Value $_{\mathrm{t}}=$ insider aggregate value on day $t$;

$\mathrm{D}_{\text {Tuesday }}=$ dummy variable equal to 1 if $\mathrm{t}$ is a Tuesday and 0 otherwise,

$D_{\text {Wednesday }}=$ dummy variable equal to 1 if $t$ is a Wednesday and 0 otherwise,

$\mathrm{D}_{\text {Thursday }}=$ dummy variable equal to 1 if $t$ is a Thursday and 0 otherwise,

$\mathrm{D}_{\text {Friday }}=$ dummy variable equal to 1 if $t$ is a Friday and 0 otherwise,

$\mathrm{e}_{\mathrm{t}}=$ Error term.

Table 1 shows the results of the regression models of whether aggregate value of directors' trades as a whole (buy and sell combined) varies across days of the week. The results indicate high average value for directors' trades as well as a significant t-statistics. When testing for heteroscedacity, the results show that the variance is not constant and the model perhaps needs to be adjusted. 
Table 1. Day of the week effects: the results of the dummy variable regression of directors' trades (buys and sales combined)

\begin{tabular}{cccc}
\hline value & Coefficients & Standard Errors & t-statistics \\
\hline Monday & $6,310,110$ & $1,233,764$ & 5.11 \\
Tuesday & $7,064,410$ & $1,179,178$ & 5.99 \\
Wednesday & $4,707,077$ & $1,173,995$ & 4.01 \\
Thursday & $5,271,727$ & $1,172,853$ & 4.49 \\
Friday & $5,695,275$ & $1,189,754$ & 4.79 \\
Heteroscedacity Test & & 0.000 & \\
\hline
\end{tabular}

Diagrammatically, Figure 1 shows the distribution of directors' aggregate value of trade across days of the week. This figure shows that some trades in Monday and Tuesday are extremely high in value which might bias our results.

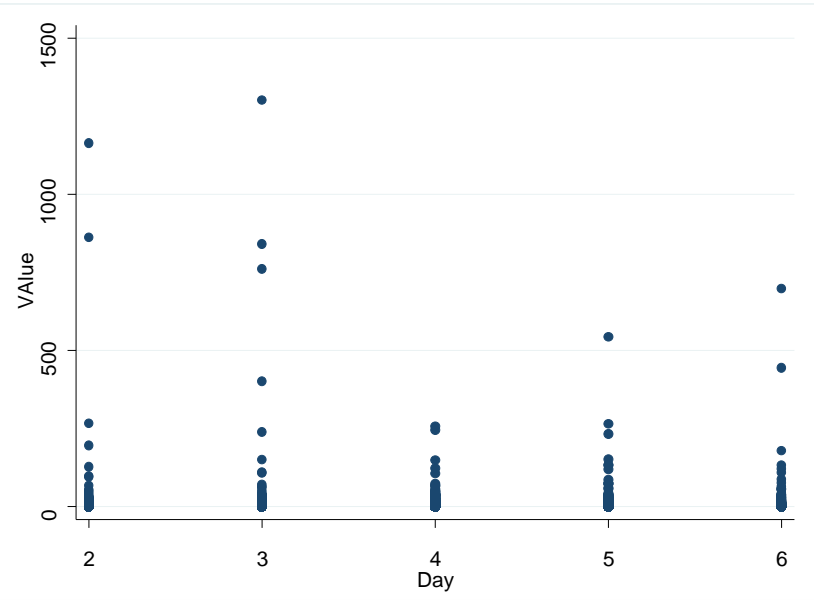

Figure 1. The distribution of insiders' aggregate value across days of the week

Figure 2 plots regression residuals against regression leverage. Leverage is a measure of how far an independent variable deviates from its mean. This figure shows that some observations have high residuals, some observations have high leverage and some of them have the both. For example, there are many trades on Tuesday which have high residuals and high leverage (see the upper right observation). Another example is an observation on the bottom right with high residual, but low leverage.

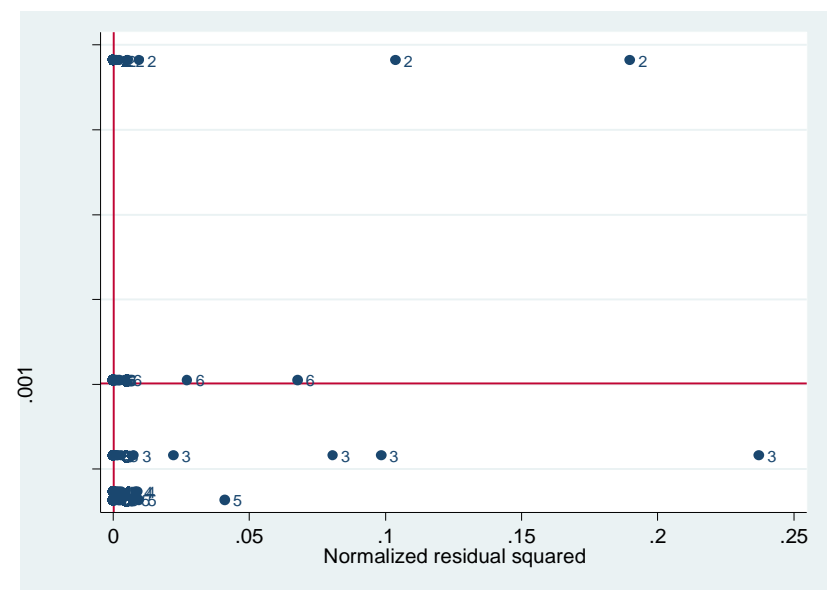

Figure 2. Regression residuals and leverages 
Therefore, to avoid the bias that might occur because of these transactions, we are going to:

1) Re-run the OLS model by using the logarithm value instead of the total value (as a dependent variable) to reduce the effects of these transactions on our results. This method was previously used by Nghiem et al., (2012).

2) Re-run the OLS model after excluding transactions whose values are more than $£ 15$ million. In this case, the total value of directors' trades is the dependent variable; and

Re-run a TOBIT regression model which is a censored form of OLS model normally used when the sample is biased to the left or to the right. This model would automatically eliminate the values that might cause biases to the results (In the cases where the values are not biased to the left or to the right, the results are similar to those calculated using OLS model). This step is similar to the previous one except that it would exclude transactions with small values. Thus, the results for the last two methods, sometimes, might be the same or might have small differences. Sometimes TOBIT Regression Model is considered as a Robust Regression Model to control for Heteroscedacity and normality problems.

However, the methodology used in this paper is to test whether there is a day of the week or month of the year anomalies in aggregate directors' trades as measured by the aggregate value (and number) of insider transactions [hypotheses (1) and (3)], whether directors' buy volume on Monday is higher compared to other days of the week [hypothesis (2)] and whether directors sell more in March and December [hypothesis (4)] by estimating the following regression models:

$$
\begin{gathered}
\text { Value }_{t}=\beta_{\text {Monday }} D_{\text {Monday }}+\beta_{\text {Tuesday }} D_{\text {Tuesday }}+\beta_{\text {Wednesday }} D_{\text {Wednesday }}+\beta_{\text {Thursday }} D_{\text {Thursday }}+ \\
\beta_{\text {Friday }} D_{\text {Friday }}+e_{t} \\
\text { Number of trades } \\
\beta_{\text {Monday }} D_{\text {Monday }}+\beta_{\text {Tuesday }} D_{\text {Tuesday }}+\beta_{\text {Wednesday }} D_{\text {Wednesday }}+ \\
\beta_{\text {Thursday }} D_{\text {Thursday }}+\beta_{\text {Friday }} D_{\text {Friday }}+e_{t}
\end{gathered}
$$

Where,

Value $_{t}=$ the logarithm of insider aggregate value (or the total value of directors' trades) on day $t$;

Number of trades $_{t}=$ Insider aggregate number of trades on day $t$;

To test the linear combination of coefficients of the OLS model, we conducted an F-test. The null hypothesis is that all the coefficients in the regression model are the same against the alternative hypothesis that at least one of the coefficients is not equal.

$$
H_{0}: \beta_{\text {Monday }}=\beta_{\text {Tuesday }}=\beta_{\text {Wednesday }}=\beta_{\text {Thursday }}=\beta_{\text {Friday }}
$$

Similarly, to test the monthly patterns, we construct almost an identical model. This model has been used by, for instance, Mehdian and Perry (2001). Therefore, we employ the following regression:

$$
\begin{aligned}
& \text { Value }_{t}=\beta_{\text {January }} D_{\text {January }}+\beta_{\text {Febuary }} D_{\text {Febuary }}+\beta_{\text {March }} D_{\text {March }}+\cdots+\beta_{\text {November }} D_{\text {November }} \\
& +\beta_{\text {December }} D_{\text {December }}+e_{t} \\
& \text { No of } \text { Trades }_{t}=\beta_{\text {January }} D_{\text {January }}+\beta_{\text {Febuary }} D_{\text {Febuary }}+\beta_{\text {March }} D_{\text {March }}+\cdots+\beta_{\text {November }} D_{\text {November }}+ \\
& \beta_{\text {December }} D_{\text {December }}+e_{t}
\end{aligned}
$$

where Value $_{t}$ is the logarithm of the aggregate value of directors' trades (or the total value of directors' trades). $D_{\text {January }}$ through $D_{\text {December }}$ are dummy variables for each month of the year, such that $D_{\text {January }}$ takes a value of 1 for all January observations and zero otherwise, and so on. $e_{t}$ is the disturbance term. Again, we can consider our null hypothesis as follows:

$$
H_{0}: \beta_{\text {January }}=\beta_{\text {Febuary }}=\beta_{\text {Wednesday }}=\beta_{\text {March }}=\cdots=\beta_{\text {December }}
$$

Our purpose here is to examine whether the aggregate value (and number) of directors' trades is statistically different on a particular month compared to other months of the year. The alternative to the null hypothesis would indicate statistically significant monthly seasonality.

Similar to previous studies in colander anomalies such as Lim et al. (2010) and Khan et al. (2013), we used Kruskal-Wallis one way analysis of variance by ranks, which is a non-parametric method To test equality of means across groups and Kruskal-Wallis test assumes that the residuals are not necessary to be normally distributed. 
The Kruskal Wallis test statistic is:

$$
H=\frac{12}{n(n+1)} \sum_{i=1}^{k} \frac{R_{i}^{2}}{n_{i}}-3(n+1)
$$

Where $R$ is the sum of the ranks for group $i$.

The null hypothesis is that the average values (numbers) of directors' trades across all the trading days are equal. If the Kruskal-Wallis statistic is less than the critical chi value, it implies that the null hypothesis should not be rejected, and that average values (number) of directors' trades across the week-days are not significantly different from each other.

\section{Results}

This section reports the empirical results of the study. First, summary statistics is resented to highlight the trends and patterns of UK directors' trades. Second, we test the hypotheses whether directors' aggregate value (and number) of trades are significantly different across days of the week or months of the year using the dummy variable regression and K-W statistic test, which was discussed earlier in the methodology section.

\subsection{Summary Statistics}

Table 2 presents summary statistics categorised by transaction type (buys and sales only) during the sample period. The sample includes 91,970 trades divided into 69,967 buy trades and 22,003 sale ones over the period 1991 to 2010, with a total monetary value of $£ 28.9$ billion. There are approximately three times as many buy trades as sells. Although buy trades are more frequent than sell trades, the average value of sell trades is approximately seven times larger, which suggests that directors sell less frequently but in larger monetary amounts (a similar argument can be said to volume). The average value of directors' purchases was $£ 122,184$, but the average value of sales was $£ 928,788$, so directors' sales are fewer in number but much larger in value.

The last column of Table 2 shows the number of days during the period in which at least one buy (sell) takes place. There are approximately 4,979 event dates (99.5\% of sample days) for buy trades and 4,583 event dates (91.6\% of sample days) for sell trades. During our sample period, there are trades of on average of thirteen buy trades (five sell trades) per event date.

Table 2. Summary statistics categorised by transaction type 1991-2010

\begin{tabular}{ccccccc}
\hline Type & No of Trades & Total Value $(\mathfrak{f})$ & Total Volume & Avg Value $£$ & Avg Volume & No of Days \\
\hline BUY & 69,967 & $8,548,845,389$ & $8,615,507,651$ & 122,184 & 123,137 & 4979 \\
SELL & 22,003 & $20,436,128,362$ & $11,044,602,967$ & 928,788 & 501,959 & 4583 \\
Total & 91,970 & $28,984,973,750$ & $19,660,110,618$ & & & \\
\hline
\end{tabular}

Average value of buy (sell) trades is the total value of buy (sell) trades divided by the total number of buy (sell) trades. Volume of buy (sell) trades presents the total number of shares that directors buy (sell). Average volume of buy (sell) trades the volume of buy (sell) trades divided by the total number of buy (sell) trades.

Table 3 reports summary statistics related to our sample categorised by both days and transaction type during the sample period. There are more buy trades than sell trades in all days. The majority of buys and sales occurred on Fridays. Buys and sales on Mondays are much less frequent. Although it is not shown in Table 3 directly, the number of buy trades by day is approximately three times the total number of sell trades per day. The average value (per day) of directors' buy transactions (and sell transactions) on Mondays (and Tuesday) is the highest whereas the average value (per trade) of directors' buy transactions (and sell transactions) on Mondays (Tuesdays) is the highest.

Table 3. Summary statistics of daily directors' buys and sells over the period 1991-2010

\begin{tabular}{ccccccc}
\hline \multirow{2}{*}{ Days } & \multicolumn{3}{c}{ Directors' Buy Trades } & \multicolumn{2}{c}{ Directors' Sell Trades } \\
\cline { 2 - 7 } & No of Trades & Avg Value/Day $(\mathfrak{f})$ & Avg Value/Trade $(\mathfrak{f})$ & No of Trades & Avg Value/Day $(\mathfrak{f})$ & Avg Value/Trade $(\mathfrak{f})$ \\
\hline Monday & 12,750 & $3,086,676$ & 223,693 & 4,091 & $3,524,595$ & 735,762 \\
Tuesday & 13,715 & $2,192,718$ & 161,956 & 4,327 & $5,406,626$ & $1,147,049$ \\
Wednesday & 14,274 & 878,470 & 62,774 & 4,555 & $4,180,045$ & 863,539 \\
Thursday & 14,508 & 935,616 & 66,037 & 4,397 & $4,720,915$ & $1,014,616$ \\
Friday & 14,720 & $1,626,303$ & 110,151 & 4,633 & $4,402,765$ & 878,082 \\
\hline
\end{tabular}


Average value per day is the total value of the trade (buy or sell) divided by the number of days. For example, the average value of buy trades on Mondays is equal to the total value of buy trades on that day divided by the number of Mondays in our sample. Average value per trade is equal to the total value of the trade (buy or sell) on a specific day divided by the number of trades on that day. The same thing can be said for the average volume per day and per trade.

Table 4 reports summary statistics related to our sample categorised by both months and transaction type during the sample period. There are more buy trades than sell trades in all months. The majority of buys and sales occurred in March. Buys and sales on February and August respectively are much less frequent.

Although it is not shown directly in Table 3, the number of buy trades by month is approximately three times the total number of sell trades per month. The average value (per month) of directors' buy transactions (and sell transactions) in April (and June) is the highest whereas the average value (per trade) of directors' buy transactions (and sell transactions) on May (October) is the highest.

Table 4. Summary statistics of monthly directors' buys and sells over the period 1991-2010

\begin{tabular}{|c|c|c|c|}
\hline Months & No of Trades & Avg Value/Month (f) & Avg Value/Trade (£) \\
\hline \multicolumn{4}{|c|}{ Directors' Buy Trades } \\
\hline January & 5,155 & $14,900,000$ & 57,841 \\
\hline February & 4,099 & $21,900,000$ & 106,757 \\
\hline March & 7,109 & $27,800,000$ & 78,290 \\
\hline April & 6,003 & $72,500,000$ & 241,460 \\
\hline May & 5,254 & $66,500,000$ & 253,197 \\
\hline June & 6,345 & $20,700,000$ & 65,392 \\
\hline July & 6,301 & $51,500,000$ & 163,555 \\
\hline August & 4,659 & $49,100,000$ & 210,744 \\
\hline September & 6,941 & $22,100,000$ & 63,701 \\
\hline October & 6,437 & $17,000,000$ & 52,673 \\
\hline November & 5,439 & $19,100,000$ & 70,065 \\
\hline December & 6,225 & $44,400,000$ & 142,508 \\
\hline \multicolumn{4}{|c|}{ Directors' Sell Trades } \\
\hline January & 1,676 & $47,600,000$ & 568,458 \\
\hline February & 1,625 & $48,900,000$ & 602,434 \\
\hline March & 2,907 & $114,000,000$ & 781,381 \\
\hline April & 2,911 & $74,900,000$ & 514,875 \\
\hline May & 1,841 & $66,100,000$ & 717,934 \\
\hline June & 1,974 & $139,000,000$ & $1,411,424$ \\
\hline July & 1,508 & $93,300,000$ & $1,237,655$ \\
\hline August & 1,198 & $44,500,000$ & 743,339 \\
\hline September & 1,796 & $106,000,000$ & $1,179,106$ \\
\hline October & 1,430 & $119,000,000$ & $1,664,113$ \\
\hline November & 1,415 & $88,200,000$ & $1,246,490$ \\
\hline December & 1,722 & $80,400,000$ & 933,944 \\
\hline
\end{tabular}

Average value per month is the total value of the trade (buy or sell) divided by the number of months. For example, the average value of buy trades on January is equal to the total value of buy trades on that month divided by the number of January in our sample. Average value per trade is equal to the total value of the trade (buy or sell) on a specific month divided by the number of trades on that month. The same thing can be said for the average volume per day and per trade.

\subsection{Day of the Week Effect}

The previous literature on calendar anomalies has been on returns. This literature has attempted to simply identify whether these anomalies exists and/or to try to explain their existence. For example, Cross (1973), French (1980), Arsad and Coutts (1997), and Gregoriou, Kontonikas and Tsitsianis (2004) reported negative returns on Monday, whereas Solnik and Bousquer (1990) indicated strong and negative returns on Tuesday. Also, studies such as Agrawal and Tandon (1994) and Balaban $(1995,1996)$ reported positive returns on Friday. These 
anomalies are perhaps due to the methodology employed or the way of calculating returns, investor psychology, the difference in trading patterns of individual and institutional investors, or settlement procedures.

Lakonishok and Maberly (1990), Abraham and Ikenberry (1994) and Sias and Starks (1995) found low trading volume on Monday for institutional investors and the opposite pattern for individual investors (i.e. high trading volume on Monday). They reasoned that individual investors have more time to devote to financial decisions during the weekend, whereas institutional investors are less active in the market on Monday because Monday tends to be a day of strategic planning. Also, Sias and Starks (1995) found that informed investors tend to trade more on Mondays because private information is available all days of the week including weekends.

Based on these priors, this section examines the seasonal patterns in aggregate insider trading transactions (as measured by the aggregate insider number and value of insider transactions). Specifically, do insiders prefer to trade on any particular day of the week [hypothesis (1) and hypothesis (2)]? Given that such seasonal patterns exist, we attempt to relate these patterns to explanations drawn from the literature on calendar anomalies.

We use the regression model discussed earlier in the methodology section (Equations 2, and 3) where the dependent variable is the logarithm value (or the total value of directors' trades) and the aggregate number of directors' trades, whilst the independent variables are dummy variables which present days of the week.

Beside examining the day effects on directors' trades as a whole, we deliberately chose to split our sample into directors' buys and sells in order to examine hypothesis (2) which indicates that trading volume of directors' buys on Mondays are higher relative to other days of the week.

Tables 5, 6, and 7 show the results of the different regressions on the aggregate value (and number) of directors' trades during the sample period. More specifically, Table 5 shows the results of the regression models of whether aggregate value (and number) of directors' trades as a whole (buy and sell combined) varies across days of the week, Table 6 shows the results of the regression models of whether aggregate value (and number) of directors' buys varies across days of the week, and Table 7 shows the results of the regression models of whether aggregate value (number) of directors' sells varies across days of the week.

One clear pattern emerges from Table 4 where, for the period 1991-2010, director trading value is the lowest on Tuesday relative to other days of the week. The null hypothesis that director trading value is the same across all days of the week can be rejected at the five per cent level (based on an F-test). In addition, director trading value appears to be slightly higher on Friday. A comparison of Tuesday versus other days indicates a tendency for Tuesday to become less active. Excluding Tuesday, the null hypothesis that the trading value is the same can be accepted. These results are repeated after excluding trades with more than $£ 15$ million and also after using TOBIT Model. Moreover, the average value of Tuesday trades is $£ 2.52$ which is approximately $15 \%$ less than the average value of Friday and Monday trades.

Similarly, Tuesday's (Friday's) average number of directors' trades is the lowest (the highest) relative to the other remaining four days. The results of the F-test confirm the latter. These results support Hypothesis (1), which states that there is no difference in aggregate director trading activities as measured by the aggregate number and value of directors' trades across days of the week. The results show that Tuesday's number of trades (and value) is less frequent, whereas Friday's number of trades (and value) is more frequent. In other words, Hypothesis (1) is rejected for director aggregate value and number of directors' trades. Another pattern emerges from the results of OLS after excluding large trades, and from the TOBIT regression model; the pattern is that the distribution of the average value of directors' trades across the week days forms a U shape i.e. high trading value on the beginning of the week (Monday) and the end of the week (Friday).

The results of OLS Model excluding trades whose values are more than $£ 15$ million are similar to those obtained using TOBIT Model except for Friday. This is because TOBIT Regression Model excludes small trades in addition to the large ones. The results of F-test in the last row represent the test of the hypothesis whether the coefficients are statistically different from each other and not whether the coefficients jointly different from zero. The F-test, for example, for testing the hypothesis whether the coefficients are jointly different from zero is 2.96 (0.0187) for the first regression. The Heteroscedacity test shows that the variance is constant.

To summarise, there seems to be a day of the week anomaly in aggregate insider transactions as measured by the aggregate value and number of insider transactions. More specifically, lower Tuesday and higher Friday trades. Therefore, insiders have a preference to trade more on Friday and less on Tuesday. The aggregate value of director transactions, which is higher on Friday and lower on Tuesday, is consistent with the previous studies such as Agrawal and Tandon (1994) and Balaban (1995, 1996) which reported positive returns on Friday and negative returns on Tuesdays. 
Table 5. Day of the week effects: the results of the dummy variable regression of directors' trades (buys and sales combined)

\begin{tabular}{|c|c|c|c|c|c|c|c|c|}
\hline \multirow[t]{2}{*}{ Day } & \multirow{2}{*}{$\begin{array}{c}\text { OLS Model (log } \\
\text { Values) } \\
\text { Coefficient }\end{array}$} & \multicolumn{2}{|c|}{$\begin{array}{c}\text { OLS Model (Total Values } \\
\text { Excluding Outliers) }\end{array}$} & \multicolumn{3}{|c|}{ TOBIT Model (Total Values) } & \multicolumn{2}{|c|}{ Number of trades } \\
\hline & & t-test & $\begin{array}{l}\text { Coefficient } \\
\text { (Millions) } \\
\end{array}$ & t-test & $\begin{array}{l}\text { Coefficient } \\
\text { (Millions) } \\
\end{array}$ & t-test & Coefficient. & t-test \\
\hline Monday & 14.08 & 277.41 & 3.002 & 21.51 & 3.003 & 22.21 & 18.13 & 49.98 \\
\hline Tuesday & 13.99 & 288.39 & 2.527 & 18.94 & 2.527 & 18.94 & 17.74 & 51.17 \\
\hline Wednesday & 14.10 & 292.13 & 2.700 & 20.33 & 2.700 & 20.33 & 18.35 & 53.17 \\
\hline Thursday & 14.12 & 292.67 & 2.934 & 22.11 & 2.934 & 22.11 & 18.39 & 53.33 \\
\hline Friday & 14.22 & 290.59 & 3.039 & 22.57 & 3.036 & 22.55 & 19.37 & 55.38 \\
\hline Heteroscedacity Test & $\begin{array}{c}0.25 \\
(0.6167) \\
\end{array}$ & & 59 & & & & $\begin{array}{l}.00 \\
9694) \\
\end{array}$ & \\
\hline $\begin{array}{l}\beta_{\text {Monday }}=\beta_{\text {Tuesday }} \\
=\beta_{\text {Wednesday }} \\
=\beta_{\text {Thursday }} \\
=\beta_{\text {Friday }} \\
\quad(\text { F-test })\end{array}$ & 2.96 & & & & 2.65 & & 2.98 & \\
\hline
\end{tabular}

Previous studies on trading volume anomalies found that informed investors tend to trade more on Mondays because private information is available all days of the week including weekends, whereas other studies indicates Tuesday effect in trading volume in other markets rather than US and reasoned that as a reflection of trades by informed investors on Monday. On the other side, studies by lakonishok and Maberly (1990) and Abraham and Ikenberry (1994) suggested that individual investors sell more (buy less) on Monday because they have more time to think about their decisions during the weekends. Our results find Friday and Tuesday effects in average number of directors' trades which reflects the desire for insiders to trade more on Friday and less on Tuesday. One possible explanation, based on the previous studies, is that insiders act like institutional investors who trade less on Tuesday as a reflection of insiders' trades on Monday in US. Also, bearing in mind that the aim of the previous studies in trading volume anomalies is to explain the calendar anomalies in stock returns, our results were consistent with studies on stock returns anomalies that show high returns on Friday and lower returns on Tuesdays. Therefore, these results might explain the seasonal pattern in stock returns.

The U shape pattern (in average value of directors' trades) observed when running OLS (excluding trades over $£ 15$ million) and TOBIT model can be attributed to price changes from larger(smaller) trades which are higher (lower) at the beginning and end of the day. In our case, to price changes from larger (smaller) trades are higher (lower) in the beginning and at the end of week. This is attributed to the view that smaller trades would move prices during periods of low volume because informed traders do not want to reveal their information to the market. When volume is low, informed traders are able to increase their trade sizes because high volume hides their information (Blau et al., 2012).

\subsubsection{Directors' Buys}

Table 6 reports the results of the regression models on daily aggregate value (number) of directors' buys during the sample period. One clear pattern emerges from Table 5 is that the coefficient of Friday is higher than the coefficients of other days of the week, whereas the coefficient of Tuesday is the lowest compared to other days' coefficients. The null hypothesis that the director trading value is the same across all days of the week cannot be rejected at the five per cent level (based on an F-test). Again, the results of OLS Model (after excluding outliers) and TOBIT Model confirm the previous findings that there is no day of the week anomaly in aggregate value of directors' buy transactions.

Table 6 also shows that the average number of directors' trades is lowest on Tuesday relative to other days of the week. The null hypothesis that the average number of directors' trades is the same across all days of the week can be rejected at the five per cent level (based on an F-test). In addition, the average number of directors' trades appears to be slightly higher on Friday. A comparison of Tuesday versus other days indicates a tendency for Tuesday to become less active and tendency for Friday to be more active.

These results fail to support Hypothesis (1) since they indicate no day of the week effect in aggregate directors' 
trading value. The results also show that Tuesday's number of trades is less frequent, whereas Friday's number of trades is more frequent. In other words, Hypothesis (1) is rejected for director aggregate number of directors' trades, but it isaccepted for directors' aggregate value.

Hypothesis (2) states that buy trading volume is higher on Monday compared to other days of the week. Our results show that Friday's average number of trades is higher (and Tuesday average number of trades is lower) compared to other days of the week. Hence, we rejected hypothesis (2). Thus, the buy trading volume on Friday is higher than other days of the week. Again, the distribution of the average value of directors' buy trades across the week days forms a U shape i.e. high trading value on the beginning of the week (Monday) and the end of the week (Friday).

Table 6. Day of the week effects: the results of the dummy variable regression of directors' buys

\begin{tabular}{|c|c|c|c|c|c|c|c|c|}
\hline \multirow[t]{2}{*}{ Day } & \multirow{2}{*}{$\begin{array}{c}\text { OLS Model } \\
\text { (log Values) }\end{array}$} & \multicolumn{2}{|c|}{$\begin{array}{c}\text { OLS Model (Total Values } \\
\text { Excluding Outliers) }\end{array}$} & \multicolumn{3}{|c|}{ TOBIT Model (Total Values) } & \multicolumn{2}{|c|}{ Number of trades } \\
\hline & & t-test & $\begin{array}{c}\text { Coefficient } \\
\text { (Millions) }\end{array}$ & t-test & $\begin{array}{l}\text { Coefficient } \\
\text { (Millions) }\end{array}$ & t-test & Coefficient. & t-test \\
\hline Monday & 12.66 & 240.83 & 0.824 & 17.99 & 0.819 & 17.83 & 13.72 & 43.98 \\
\hline Tuesday & 12.58 & 250.46 & 0.697 & 15.92 & 0.693 & 16.12 & 13.49 & 45.21 \\
\hline Wednesday & 12.64 & 252.78 & 0.731 & 16.76 & 0.725 & 16.59 & 13.91 & 46.85 \\
\hline Thursday & 12.65 & 253.06 & 0.770 & 17.68 & 0.767 & 17.55 & 14.11 & 47.57 \\
\hline Friday & 12.77 & 251.86 & 0.794 & 17.97 & 0.792 & 17.88 & 14.73 & 48.96 \\
\hline Heteroscedacity Test & $\begin{array}{c}0.14 \\
(0.7130) \\
\end{array}$ & \multicolumn{2}{|c|}{$\begin{array}{c}2.63 \\
(0.6219) \\
\end{array}$} & \multicolumn{5}{|c|}{$\begin{array}{c}2.36 \\
(0.1248) \\
\end{array}$} \\
\hline $\begin{array}{l}\boldsymbol{\beta}_{\text {Monday }}=\boldsymbol{\beta}_{\text {Tuesday }} \\
=\boldsymbol{\beta}_{\text {Wednesday }} \\
=\boldsymbol{\beta}_{\text {Thursday }} \\
=\boldsymbol{\beta}_{\text {Friday }} \\
\quad(\text { F-test })\end{array}$ & 1.69 & \multicolumn{2}{|c|}{1.28} & \multicolumn{2}{|c|}{1.31} & \multicolumn{3}{|c|}{2.36} \\
\hline
\end{tabular}

The results of F-test in the last row represent the test of the hypothesis whether the coefficients are statistically different from each other and not whether the coefficients jointly different from zero.

To summarise, it looks like there is no day of the week anomaly in aggregate value of directors' trades. Also, the aggregate number of directors' trades is higher on Friday and lower on Tuesday which indicates the existence of the day of the week effect in insider aggregate number of trades. This reflects the desire of directors to trade more on Friday (and less on Tuesday).

\subsubsection{Directors' Sells}

Table 7 reports the results of the regression models on the aggregate value (number) of directors' sells during the sample period. One clear pattern emerges from Table 7 is that the coefficient of Friday is higher than the coefficients of other days of the week, whereas the coefficient of Tuesday is the lowest compared to other days' coefficients. The null hypothesis that the director trading value is the same across all days of the week cannot be rejected at the five per cent level (based on an F-test). These results are again repeated after excluding trades with more than $£ 15$ and also after using TOBIT Model. Moreover, the average value of Tuesday sells is $£ 1.55$ which is approximately $20 \%$ less than the average value of Friday and Monday trades.

In the same vein, it appears that there is no day of the week effect in director trading selling activities as measured by the aggregate number of directors' sell trades. Back to Hypothesis (1), the results indicate no day of the week effect in aggregate directors' trading value and number. In other words, Hypothesis (1) is accepted for directors' aggregate value, number and volume. Given that there is no day of the week anomaly in director trading volume, Hypothesis (2) is also rejected. 
Table 7. Day of the week effects: the results of the dummy variable regression of directors' sells

\begin{tabular}{|c|c|c|c|c|c|c|c|c|}
\hline \multirow[t]{2}{*}{ Day } & \multirow{2}{*}{$\begin{array}{c}\text { OLS Model } \\
\text { (log Values) } \\
\text { Coefficient }\end{array}$} & \multicolumn{2}{|c|}{$\begin{array}{l}\text { OLS Model (Total Values } \\
\text { Excluding Outliers) }\end{array}$} & \multicolumn{3}{|c|}{ TOBIT Model (Total Values) } & \multicolumn{2}{|c|}{ Number of trades } \\
\hline & & t-test & Coefficient (Millions) & $\mathrm{t}$-test & Coefficient (Millions) & t-test & Coefficient. & t-test \\
\hline Monday & 12.36 & 95.65 & 2.177 & 17.08 & 1.962 & 14.7 & 4.40 & 32.92 \\
\hline Tuesday & 12.14 & 98.36 & 1.830 & 15.02 & 1.559 & 11.89 & 4.25 & 33.28 \\
\hline Wednesday & 12.40 & 100.87 & 1.969 & 16.23 & 1.737 & 13.34 & 4.44 & 34.88 \\
\hline Thursday & 12.42 & 101.16 & 2.163 & 17.85 & 1.945 & 14.96 & 4.28 & 33.64 \\
\hline Friday & 12.59 & 101.08 & 2.244 & 18.25 & 2.042 & 15.5 & 4.64 & 35.95 \\
\hline Heteroscedacity Test & $\begin{array}{c}0.03 \\
(0.8549) \\
\end{array}$ & & $\begin{array}{c}5.53 \\
(0.2372) \\
\end{array}$ & & & & $\begin{array}{c}0.02 \\
0.8938) \\
\end{array}$ & \\
\hline $\begin{array}{l}\boldsymbol{\beta}_{\text {Monday }}=\boldsymbol{\beta}_{\text {Tuesday }} \\
=\boldsymbol{\beta}_{\text {Wednesday }} \\
=\boldsymbol{\beta}_{\text {Thursday }} \\
=\boldsymbol{\beta}_{\text {Friday }} \\
\quad(\text { F-test })\end{array}$ & 1.29 & & 1.97 & & 2.26 & & 0.7563 & \\
\hline
\end{tabular}

The results of F-test in the last row represent the test of the hypothesis whether the coefficients are statistically different from each other and not whether the coefficients jointly different from zero.

To summarise, the aggregate value (number) of sale trades does not vary across days of the week. Instead, we can say that directors' trades, in general, on Tuesdays and Wednesdays are the lowest relative to other days of the week.

\subsubsection{Summary of Day of the Week Anomalies Results}

To summarise, the results show that there is no day of the week effects in aggregate value of directors' buys and sells, but it looks like there is a Tuesday effect in aggregate value of directors 'trades when buys and sells are combined together. An examination of the existence of Tuesday effects was previously conducted in stock returns (Agrawal \& Tandon, 1994; Martikainen \& Puttonen, 1996; and Brooks \& Persand, 2001) and in trading volume (Badhani, 2006).

The distribution of the average value of directors' trades (buys and sells) across the week days forms a U shape i.e. high trading value on the beginning of the week (Monday) and the end of the week (Friday). The U shape pattern (in average value of directors' trades) is perhaps due to price changes from larger (smaller) trades which are higher (lower) at the beginning and end of the week. This is because smaller trades would move prices during periods of low volume because informed traders do not want to reveal their information to the market. When volume is low, informed traders are able to increase their trade sizes because high volume hides their information (Blau et al., 2012).

Also, the aggregate number of directors' trades (buy and sell combined and buy transactions) is higher on Friday and lower on Tuesday which means that there is a day of the week effect in insider aggregate number of trades. One possible explanation, based on the previous studies, is that insiders act like institutional investors who trade less on Tuesday as a reflection of insiders' trades on Monday in US. Taking into accounts that the aim of the previous studies in trading volume anomalies was to explain the calendar anomalies in stock returns, our results were consistent with studies on stock returns anomalies that show high returns on Friday and lower returns on Tuesdays. Therefore, these results might explain the seasonal pattern in stock returns.

\subsection{Results of Monthly Patterns}

This literature attempts to simply identify whether these anomalies exists and/or to try to explain their existence. For example, Rozeff and Kinney (1976), Keim (1983), Mehdian and Perry (2002) and Gu (2006) found positive returns in January. The existence of this anomaly can be explained by a tax loss selling hypothesis, window dressing hypothesis, new information provided by the firms at the end of the financial year, or insider trading activities.

The volume of sales tends to be lower for losers stocks in December because investors, by postponing their sales by a month or two, postpone payments of capital tax by a full year, whereas the volume of sales for winners stocks in December because investors would apply these losses against their taxable incomes soon as possible (Dyl, 1977; Henderson, 1990). 
Seyhun (1988b) examined the monthly pattern of aggregate insider transactions in the US over the period 1975-1981, whereas Hillier and Marshall (2002) examined the January effect in UK securities. Both of these studies use the aggregate number of insider trades as their measure of insider trading activity, and both of these studies found that January returns are positive and significant.

Based on these previous findings, this section examines the seasonal patterns in aggregate insider trading transactions (as measured by the aggregate insider number and value of insider transactions). Specifically, do insiders prefer to trade on any particular month of the year [hypothesis (3)]? Given that such seasonal patterns exist, we attempt to relate these patterns to explanations drawn from the literature on calendar anomalies in returns (and volumes).

We use the regression model discussed earlier in the methodology section (Equations 4, and 5) where the dependent variable is the logarithm value (and volume) and the aggregate number of directors' trades, whilst the independent variables are dummy variables which represent months of the year. In addition to examining the monthly effects on directors' trades as a whole, we deliberately chose to split our sample into directors' buys and sells in order to examine hypothesis (4).

\subsubsection{Directors' Trades}

Table 8 presents the results of the different regression models on monthly aggregate value (number) of directors' activities during the sample period.

One clear pattern emerges from Table 8 which indicates that, for the period 1991-2010, director trading value in March is the highest relative to other months of the year. The null hypothesis that director trading value is the same across all months of the year can be accepted at the five per cent level (based on an F-test). In addition, director trading value appears to be slightly lower in February. A comparison of March versus other months indicates a tendency for March to become more active. The results of OLS Model (when excluding outliers) and the results of TOBIT Model show that March trading value is higher and significantly different from other months trading value. More specifically, the average value of directors' trades on March is $£ 84$ million which reflects the tendency for directors to trade more in March.

Table 8 also shows that the average number of directors' trades in March is the highest relative to other months of the year. The average trading number on March is 500 transactions, versus an average of 450 transactions for April. This implies a decrease of more than ten per cent in trading number in April. March's trading number is significantly different from the trading number of the remaining months. The null hypothesis that the average number of directors' trades is the same across all months of the year can be rejected at the five per cent level (based on an F-test).

Back to Hypothesis (3), which states that there is no month of the year effect in aggregate insider activities as measured by the aggregate number, value and volume of directors' trades, the results indicate no month of the year effect in aggregate directors' trading value when using logarithm value as a depended variable, but when excluding large trades and running TOBIT regression the results show March anomaly. The results also show that March's number of trades is higher.

To summarise, the average number of directors' trades varies across months of the year. More specifically, March trades' number is higher and significantly different compared to other months of the year. These results are also confirmed for directors' aggregate value of trades when excluding trades with sterling value more than $£ 15$ million and when using the TOBIT regression model. Thus, directors prefer to trade more in March (either buy or sell).

Table 8. Monthly effect: the results of the dummy variable regression on directors' trades

\begin{tabular}{|c|c|c|c|c|c|c|c|c|}
\hline \multirow[t]{2}{*}{ Month } & \multicolumn{2}{|c|}{$\begin{array}{l}\text { OLS Model (logarithm } \\
\text { Values) }\end{array}$} & \multicolumn{2}{|c|}{$\begin{array}{c}\text { OLS Model (Total Values } \\
\text { Excluding Outliers) }\end{array}$} & \multicolumn{2}{|c|}{ TOBIT Model (Total Values) } & \multicolumn{2}{|c|}{ Number of Trades } \\
\hline & Coefficients & t-test & Coefficients (Millions) & t-test & Coefficients (Millions) & t-test & Coefficients & t-test \\
\hline January & 17.63 & 77.79 & 44.600 & 5.14 & 43.597 & 5.14 & 341.55 & 9.5 \\
\hline February & 17.59 & 77.62 & 46.100 & 5.31 & 46.035 & 5.31 & 286.2 & 7.96 \\
\hline March & 18.30 & 80.74 & 84.100 & 9.69 & 84.140 & 9.69 & 500.8 & 13.93 \\
\hline April & 18.08 & 79.77 & 61.900 & 7.13 & 62.020 & 7.13 & 445.7 & 12.4 \\
\hline May & 18.15 & 80.08 & 65.500 & 7.55 & 65.315 & 7.55 & 354.75 & 9.87 \\
\hline June & 18.32 & 80.8 & 79.200 & 9.13 & 79.923 & 9.13 & 415.95 & 11.57 \\
\hline
\end{tabular}




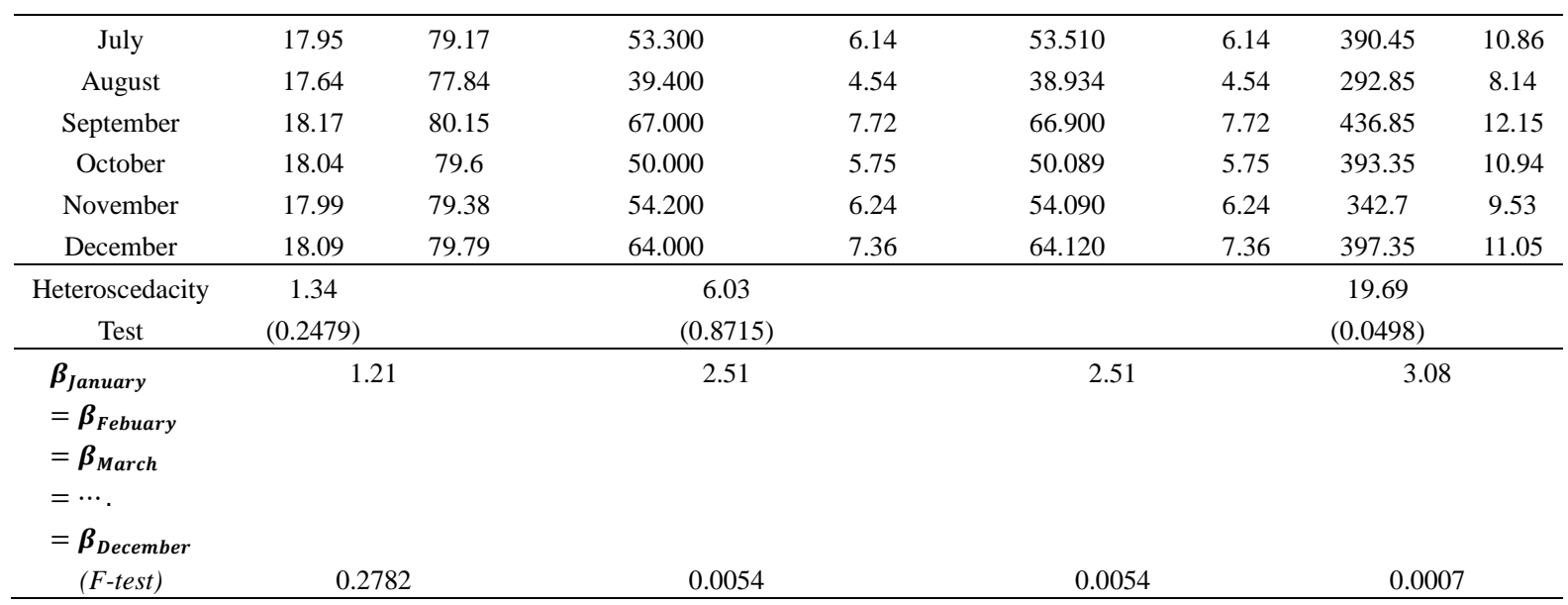

In UK, April is the month of taxation. According to the tax-loss hypothesis, investors sell more in the month before the taxation and buy more after taxation. Therefore, these results might be due to directors selling more to avoid taxes. More details are given in the next two sections when examining directors' buys and sells separately.

The results of F-test in the last row represent the test of the hypothesis whether the coefficients are statistically different from each other and not whether the coefficients jointly different from zero.

\subsubsection{Directors' Buys}

Table 9 reports the results of the OLS Model (with the usage of the logarithm of value as a dependent variable and after excluding the outliers) and the TOBIT Model on monthly aggregate value (and number) of Directors' buys during the sample period.

One clear pattern emerges from Table 9 which indicates that, for the period 1991-2010, director trading value in December is the highest relative to other months of the year. The null hypothesis that director trading value is the same across all months of the year can be accepted at the five per cent level (based on an F-test). In addition, director trading value appears to be slightly lower on February. A comparison of December versus other months indicates a tendency for December to become more active. These results are repeated (the non-existence of monthly anomalies) after excluding trades with more than $£ 15$ and also after using TOBIT Model.

Table 9 also shows that the average number of directors' trades in March is the highest relative to other months of the year. The average trading number for March is 355 transactions, versus an average of 321 transactions for October. This implies a decrease of approximately ten per cent in trading number in October. March's trading number is significantly different from the trading number of the remaining months. The null hypothesis which assumes that the average number of directors' trades is the same across all months of the year can be rejected at the five percent level (based on an F-test).

Table 9. Monthly effect: the results of the dummy variable regression on directors' buys

\begin{tabular}{|c|c|c|c|c|c|c|c|c|}
\hline \multirow[t]{2}{*}{ Month } & \multicolumn{2}{|c|}{$\begin{array}{c}\text { OLS Model (logarithm } \\
\text { Values) }\end{array}$} & \multicolumn{2}{|c|}{$\begin{array}{c}\text { OLS Model (Total Values } \\
\text { Excluding Outliers) }\end{array}$} & \multicolumn{2}{|c|}{ TOBIT Model (Total Values) } & \multicolumn{2}{|c|}{ Number of Trades } \\
\hline & Coefficients & t-test & Coefficients (Millions) & t-test & Coefficients (Millions) & t-test & Coefficients & t-test \\
\hline January & 16.20 & 66.92 & 12.500 & 4.45 & 12.465 & 4.5 & 257.75 & 7.91 \\
\hline February & 16.09 & 66.48 & 10.100 & 3.59 & 10.025 & 3.62 & 204.95 & 6.29 \\
\hline March & 16.73 & 69.11 & 19.500 & 6.95 & 19.580 & 7.07 & 355.45 & 10.9 \\
\hline April & 16.39 & 67.73 & 13.600 & 4.85 & 13.670 & 4.93 & 300.15 & 9.21 \\
\hline May & 16.56 & 68.42 & 18.400 & 6.54 & 18.415 & 6.65 & 262.7 & 8.06 \\
\hline June & 16.46 & 67.99 & 19.700 & 7.03 & 19.987 & 7.2 & 317.25 & 9.73 \\
\hline July & 16.55 & 68.38 & 16.300 & 5.8 & 16.300 & 5.88 & 315.05 & 9.67 \\
\hline August & 16.13 & 66.63 & 10.700 & 3.81 & 10.269 & 3.68 & 232.95 & 7.15 \\
\hline September & 16.44 & 67.91 & 17.700 & 6.29 & 17.715 & 6.39 & 347.05 & 10.65 \\
\hline October & 16.29 & 67.3 & 17.000 & 6.04 & 17.049 & 6.14 & 321.85 & 9.87 \\
\hline November & 16.45 & 67.94 & 16.300 & 5.79 & 16.285 & 5.88 & 271.95 & 8.34 \\
\hline December & 16.85 & 69.61 & 18.900 & 6.72 & 18.920 & 6.83 & 311.25 & 9.55 \\
\hline
\end{tabular}




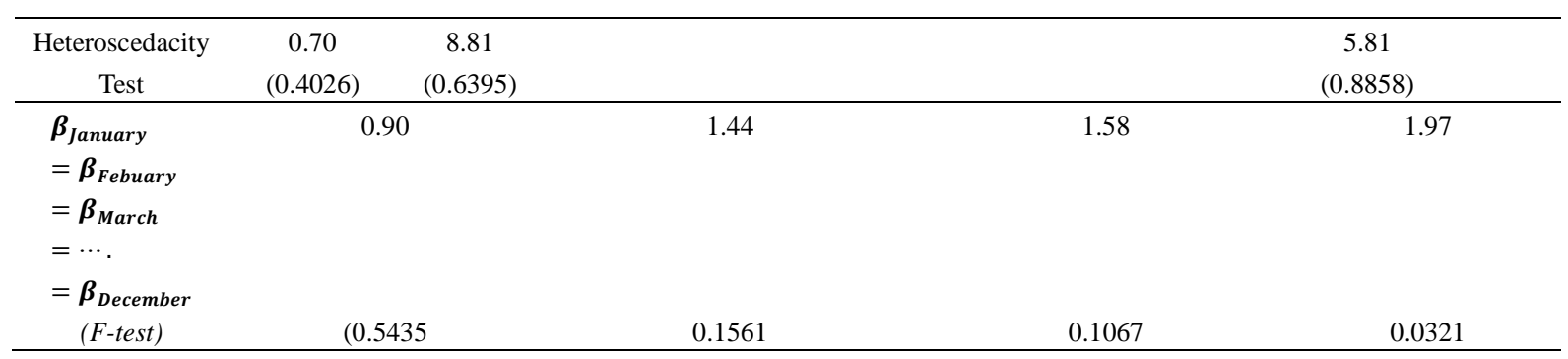

Turning to Hypothesis (3), the results indicate no month of the year effect in aggregate directors' trading value. The results also show that March's number of trades is more frequent, whereas February's number of trades is less frequent. In other words, Hypothesis (3) is rejected for director aggregate number of trades, but it is accepted for directors' aggregate value.

Also, Hypothesis (4), which suggests that Directors tend to sell more in March and buy more in April compared to other months of the year, is rejected. Thus, insiders have preferences to buy more in March.

The results of F-test in the last row represent the test of the hypothesis whether the coefficients are statistically different from each other and not whether the coefficients jointly different from zero.

To summarise, there is no monthly anomalies in aggregate insider buying activities as measured by the aggregate value of insider transactions. For director trading number of trades, March's number of buy trades is higher, which suggests that directors are more likely to trade on March than on other months of the year. According to tax loss hypothesis, we expected to find high buy trades in April, but instead we found high buying activities in March. One possible explanation is that 5th of April is the taxation date for individuals in the UK; therefore, insiders might buy till the last two weeks of March. Hence, March effect in the aggregate number of directors' trades is perhaps due to buy activities in the first twenty days of March.

\subsubsection{Directors' Sells}

Table 10 reports the results of the OLS Model (with the usage of the logarithm value as dependent variable and after excluding the outliers), and the TOBIT Model on monthly aggregate value (and number) of directors' sells during the sample period.

Table 10. Monthly effect: the results of the dummy variable regression on directors' sells

\begin{tabular}{|c|c|c|c|c|c|c|c|c|}
\hline \multirow[t]{2}{*}{ Month } & \multicolumn{2}{|c|}{$\begin{array}{l}\text { OLS Model (logarithm } \\
\text { Values) }\end{array}$} & \multicolumn{2}{|c|}{$\begin{array}{l}\text { OLS Model (Total Values } \\
\text { Excluding Outliers) }\end{array}$} & \multicolumn{2}{|c|}{ TOBIT Model (Total Values) } & \multicolumn{2}{|c|}{ Number of Trades } \\
\hline & Coefficients & t-test & Coefficients (Millions) & t-test & Coefficients (Millions) & t-test & Coefficients & t-test \\
\hline January & 17.19 & 68.15 & 32.100 & 4.41 & 31.132 & 4.32 & 83.8 & 8.44 \\
\hline February & 17.25 & 68.39 & 36.000 & 4.94 & 36.010 & 5.02 & 81.25 & 8.19 \\
\hline March & 17.92 & 71.04 & 64.600 & 8.87 & 64.560 & 9.01 & 145.35 & 14.64 \\
\hline April & 17.77 & 70.45 & 48.300 & 6.63 & 48.350 & 6.74 & 145.55 & 14.66 \\
\hline May & 17.72 & 70.25 & 47.100 & 6.47 & 46.900 & 6.54 & 92.05 & 9.27 \\
\hline June & 18.04 & 71.52 & 59.500 & 8.17 & 59.936 & 8.35 & 98.7 & 9.94 \\
\hline July & 17.58 & 69.7 & 37.000 & 5.09 & 37.210 & 5.19 & 75.4 & 7.6 \\
\hline August & 17.13 & 67.91 & 28.700 & 3.94 & 28.665 & 4 & 59.9 & 6.04 \\
\hline September & 17.81 & 70.61 & 49.300 & 6.78 & 49.185 & 6.86 & 89.8 & 9.05 \\
\hline October & 17.62 & 69.86 & 33.000 & 4.53 & 33.040 & 4.61 & 71.5 & 7.2 \\
\hline November & 17.60 & 69.76 & 37.900 & 5.2 & 37.805 & 5.27 & 70.75 & 7.13 \\
\hline December & 17.56 & 69.62 & 45.100 & 6.19 & 45.200 & 6.31 & 86.1 & 8.67 \\
\hline Heteroscedacity & 0.06 & 9.30 & & & & & 8.81 & \\
\hline Test & $(0.8139)$ & $(0.5938)$ & & & & & $(0.6393)$ & \\
\hline$\beta_{\text {January }}$ & \multicolumn{2}{|c|}{1.28} & \multicolumn{2}{|l|}{1.63} & \multicolumn{2}{|l|}{2.46} & \multicolumn{2}{|l|}{7.53} \\
\hline \multicolumn{9}{|l|}{$=\boldsymbol{\beta}_{\text {Febuary }}$} \\
\hline \multicolumn{9}{|l|}{$=\beta_{\text {March }}=\cdots$} \\
\hline \multicolumn{9}{|l|}{$=\boldsymbol{\beta}_{\text {December }}$} \\
\hline$(F$-test $)$ & \multicolumn{2}{|c|}{0.2350} & \multicolumn{2}{|l|}{0.0988} & \multicolumn{2}{|l|}{0.0063} & \multicolumn{2}{|l|}{0.000} \\
\hline
\end{tabular}


One clear pattern emerges from Table 10 which indicates that, for the period 1991-2010, the director trading value in June is the highest relative to other months of the year. The null hypothesis which states that director trading value is the same across all months of the year can be accepted at the five per cent level (based on an F-test). In addition, director trading value appears to be slightly lower in August. A comparison of June versus other months indicates a tendency for June to become more active. These results are repeated (the non-existence of monthly anomalies) after excluding trades with more than $£ 15$ but not after using TOBIT Model. The results of TOBIT Regression Model show that the average value of directors' selling activities in March is higher and significantly different relative to other months of the year. The average value of March's sells is $£ 64$ million, which suggests that directors prefer to trade more in this month.

Table 10 also shows that the average number of directors' trades in March and April is the highest relative to other months of the year. The average trading number on March and April are approximately the same (145 transactions). March and April's trading numbers are significantly different from the trading numbers of the remaining months. The null hypothesis which assumes that the average number of directors' trades is the same across all months of the year can be rejected at the five per cent level (based on an F-test).

Excluding March and April, the null hypothesis which assumes that the average number of directors' trades is the same cannot be rejected. Back to Hypothesis (3), the results indicate no month of the year effect in aggregate directors' trading value (when using OLS Models). These results changed when using TOBIT Model suggesting the existence of March effects. The results also show that March's and April's number of trades are more frequent. In other words, Hypothesis (3) is rejected for director aggregate number of trades and accepted for directors' aggregate value and volume.

Also, Hypothesis (4), which suggests that Directors tend to sell more in March compared to other months of the year, is accepted. These results can be explained by tax loss selling hypothesis (March sell pressure) which suggests that investors sell more in the month prior to taxation date or capital gain hypothesis which states that investors delay capital gains realisation so that they can delay tax payment on capital gains. By doing so, investors might postpone tax payment by one year. Thus, investors would sell winners (shares) in April. Hence, the selling pressure in March would be small causing the price to rise.

The results of F-test in the last row represent the test of the hypothesis whether the coefficients are statistically different from each other and not whether the coefficients jointly different from zero.

Hillier and Marshall (2002a) suggested that insiders sell more 20 days before taxation date. In the UK, 5th of April is the taxation date. Therefore, we might expect insiders to sell more in the last two weeks of March and first week of April. For that reason, we re-examined calendar anomalies in aggregate insider activities as measured by the aggregate number of insider transactions in the last two weeks of March and First week of April (weeks 12, 13, 14 and 15). The evidence indicates, as can be seen from Table 11, that the average number of sell transactions in these weeks is significantly different from the average number of sell trades in other weeks. The average trading number on weeks $12,13,14$ and 15 are approximately 53 transactions.

Table 11. The results of dummy variable regression on directors' sells on weekly basis

\begin{tabular}{cccccr}
\hline Weeks & Coefficients & Standard Error & T-test & P-Value & F-test \\
\hline Weeks 12, 13, 14 and 15 & 52.84 & 2.15 & 24.59 & 0 & 207.49 \\
Other Weeks & 20.59 & 0.63 & 32.75 & 0 & \\
\hline
\end{tabular}

The estimation equation is;

The Aggregate Number of Trades ${ }_{t}=\beta_{\text {Weeks } 12,13,14, \text { and } 15} W_{\text {Weeks } 12,13,14, \text { and } 15}+\beta_{\text {Other Weeks }} W_{\text {Other Weeks }}$ Where $W_{\text {weeks } 12,13,14, \text { and } 15}$ is a dummy variable that takes the value of 1 if the trade occurred in weeks $12,13,14$, and 15 and 0 otherwise.

Figure 3 shows the distribution of the average number of sell trades over the weeks of the year. The figure shows that the average number of sell trades increase at week 12 and peak at week 15 . Thereafter, a decrease in the average number of sell trades in the following three weeks (weeks 16,17, and 18). This supports the view that directors sell more before the taxation. 


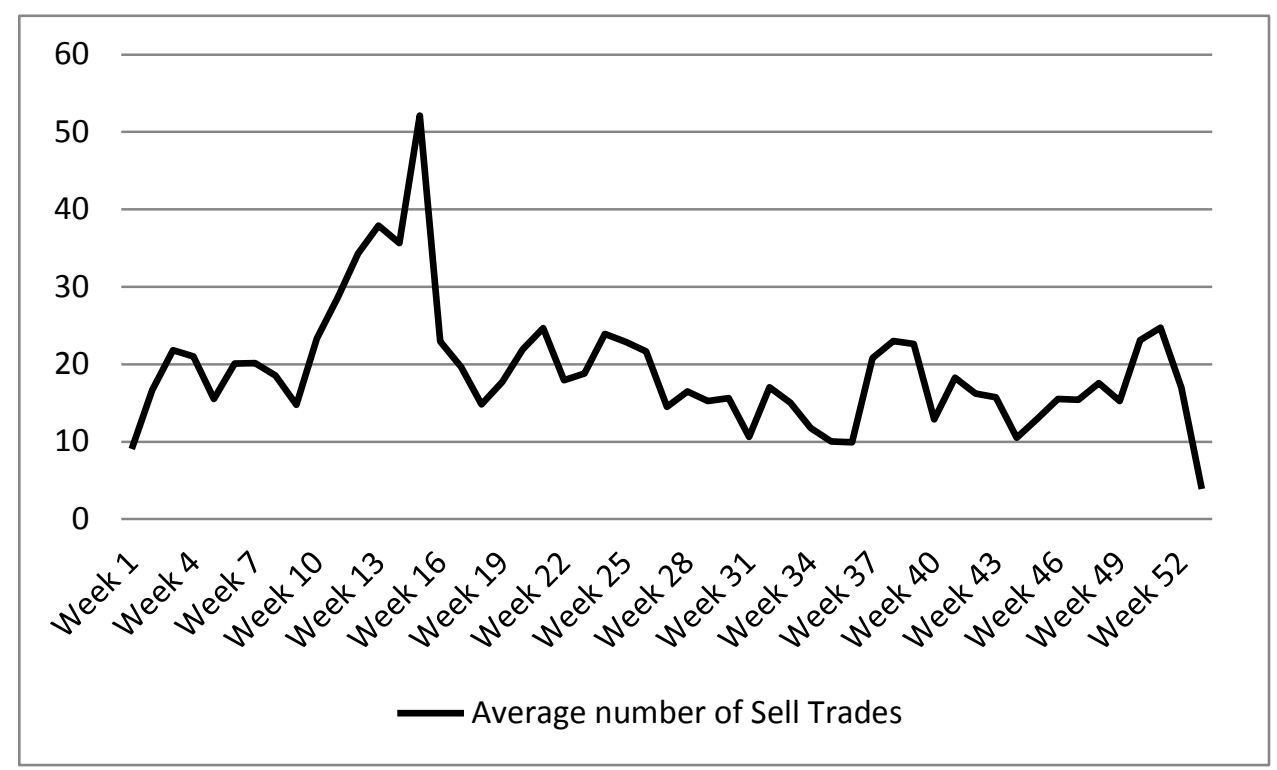

Figure 3. The distribution of the average number of directors' sells over sample weeks

To summarise, the results of OLS Regression Model indicate that there is no monthly anomalies in aggregate insider selling activities as measured by the aggregate value of insider transactions. The results of TOBIT Regression Model show that the average value of directors' selling activities in March is higher and significantly different relative to other months of the year.

In UK, April is the month of taxation. According to the tax-loss hypothesis, investors sell more in the month before the taxation and buy more after taxation. Therefore, these results might be due to directors selling more to avoid taxes. This is confirmed when we looked at directors' sell 20 days before the taxation.

\subsection{The Results of $K$-W Statistic Test}

Table 12 reports the results of K-W statistic test for insider aggregate value and number of directors' buys and sells. The table supports the results of the OLS regression model and confirms the existence of monthly anomaly in aggregate director trading activities (measured by the number of director transactions). Also, when considering buy and sell transactions as a whole, the results indicate a kind of day of the week anomaly.

Unlike the previous findings, there seems to be a day of the week effect in director aggregate value of buy trades. This difference might happen normally when OLS regression model assumptions are not met completely (Brooks, 2014; and Lim et al., 2010).

Table 12. The results of K-W statistic test

\begin{tabular}{ccccccc}
\hline & \multicolumn{2}{c}{ Buy } & \multicolumn{2}{c}{ Sell } & \multicolumn{2}{c}{ All Trades } \\
\hline & Value & No of Trades & Value & No of Trades & Value & No of Trades \\
\hline \multicolumn{7}{c}{ Day-Of-The week } \\
\hline chi-squared & 11.05 & 13.21 & 7.75 & 11.72 & 13.712 & 18.539 \\
p-value & 0.0259 & 0.0102 & 0.101 & 0.0196 & 0.0083 & 0.001 \\
\hline \multicolumn{7}{c}{ Month-Of-The year } \\
\hline chi-squared & 14.81 & 27.98 & 13.49 & 55.62 & 13.08 & 43.44 \\
p-value & 0.1912 & 0.0032 & 0.2625 & 0.0001 & 0.2879 & 0.0001 \\
\hline
\end{tabular}

To summarise, the results show the following:

1) There is a day of the week anomaly in aggregate insider activities (as measured by number and value of insider transactions). More specifically, insiders tend to trade more on Fridays and less on Tuesdays. This anomaly disappeared for directors' aggregate value when splitting the sample to directors' buys and sells. The existence of Tuesday effects was previously conducted in stock returns (Agrawal \& Tandon, 1994; Martikainen \& Puttonen, 1996; and Brooks \& Persand, 2001) and in trading volume (Badhani, 2006). 
2) The distribution of the average value of directors' trades (buys and sells) across the week days forms a U shape i.e. high trading value on the beginning of the week (Monday) and the end of the week (Friday).

3) There is a month of the year anomaly in aggregate insider activities (as measured by the number of insider transactions). More specifically, insiders tend to trade more in March (in the aggregate number) and trade less in August. For directors' buys, insider aggregate buying activities are higher in December and March, whereas, for directors' sells, insider aggregate selling activities are higher in April. These results are consistent with Seyhun (1988b) and Hillier and Marshall (2002a).

4) The results of K-W statistic test confirm the nonexistence of monthly anomaly in aggregate director trading (measured by value of director transactions). Unlike the previous findings, there seems to be a day of the week effect in director aggregate value of buy trades, which might happen normally when OLS regression model assumptions are not met completely.

\section{Conclusions}

One aim of this study was to test for seasonal patterns in aggregate insider trading transactions (as measured by the aggregate insider number and value of insider transactions). Specifically, do insiders prefer to trade on any particular day of the week or month of the year?

The literature in this paper has attempted to simply identify whether these anomalies exists and/or to try to explain their existence. It indicated the existence of the day of the week effect i.e. negative returns in the beginning of the week and high returns at the end of the week. These anomalies might be driven by the employed methodology or the way of calculating returns, investor psychology, the difference in trading patterns of individual and institutional investors, or settlement procedures. Furthermore, the literature on trading volume suggests that Monday's trading volume is higher compared to other days of the week. More specifically, investors sell more on Monday if they are individual investors and sell less if they are institutional investors. This is perhaps due to private information hypothesis and the behaviour of individual and institutional investors. Similarly, previous empirical literature on stock returns anomalies supports the existence of the month of the year effect i.e. high returns in January. These anomalies might be driven by the tax loss selling hypothesis, window dressing hypothesis, or new information provided by the firms at the end of the financial year. Also, the turn of the year effect might be due to director trading activities as measured by the aggregate number of directors' trades.

A second aim of this paper, given that such seasonal patterns exist, was to attempt to relate these patterns to explanations drawn from the literature on calendar anomalies. Using a dataset of more than 5,000 UK companies over the period January 1991 to December 2010 resulting in 91,970 trades, 70,067 buys and 22,026 sells, we carried out a series of parametric (OLS) and non-parametric (Kruskal-Wallis) tests to determine whether there is a calendar effects or not.

Our results indicated the following: There is a day of the week anomaly in aggregate insider activities (as measured by number and value of insider transactions). Specifically, insiders tend to trade more on Fridays and less on Tuesdays. The distribution of the average value of directors' trades (buys and sells) across the week days forms a $U$ shape i.e. high trading value on the beginning of the week (Monday) and the end of the week (Friday). There is a month of the year anomaly in aggregate insider activities (as measured by the number of insider transactions). Specifically, insiders tend to trade more in March (in the aggregate number) and trade less in August. For directors' buys, insider aggregate buying activities are higher in December and March, whereas, for directors' sells, insider aggregate selling activities are higher in April. These results are consistent with Seyhun (1988b) and Hillier and Marshall (2002a). The average number of sell transactions in the three weeks before taxation date is significantly different from the average number of sells trades in other weeks

These results are also confirmed by the results of K-W statistic test which supported the non-existence of monthly anomaly in aggregate director trading (measured by the value of director transactions). Unlike the previous findings, there seems to be a day of the week effect in director aggregate value of buy trades.

The existence of Friday (Tuesday) effects was previously conducted in stock returns (Agrawal \& Tandon; Martikainen \& Puttonen, 1996; and Brooks \& Persand, 2001). One possible explanation, based on the previous studies, is that insiders act like institutional investors who trade less on Tuesday as a reflection of insiders' trades on Monday in US. Taking into accounts that the aim of the previous studies in trading volume anomalies was to explain the calendar anomalies in stock returns, our results were consistent with studies on stock returns anomalies that show high returns on Friday and lower returns on Tuesdays. Therefore, these results might explain the seasonal pattern in stock returns. 
The U shape pattern (in average value of directors' trades) is perhaps due to price changes from larger (smaller) trades which are higher (lower) at the beginning and end of the week. This is because smaller trades would move prices during periods of low volume because informed traders do not want to reveal their information to the market. When volume is low, informed traders are able to increase their trade sizes because high volume hides their information (Blau et al., 2012).

The existence of March and April anomalies can be explained by tax loss selling hypothesis (March sell pressure) which suggests that investors sell more in the month prior to taxation date or capital gain hypothesis which states that investors delay capital gains realisation so that they can delay tax payment on capital gains. By doing so, investors might postpone tax payment by one year. Thus, investors would sell winners (shares) in April. Hence, the selling pressure in March would be small causing the price to rise. Tax loss selling hypothesis, as an explanation of March and April anomalies, further supported when we examined directors' sell transactions twenty days before taxation date. Although the purpose of this paper is purely to identify whether such anomalies exist, we do not attempt to explain why they do. We believe that this is an avenue for further research in this area.

\section{References}

Abraham, A., \& Ikenberry, D. L. (1994). The Individual Investor and the Weekend Effect. Journal of Financial and Quantitative Analysis, 29(2), 263-277. http://dx.doi.org/10.2307/2331225

Admati, A. R., \& Pfleiderer, P. (1988). A theory of Intraday Patterns: Volume and Price Variability. Review of Financial Studies, 1(1), 3-40. http://dx.doi.org/10.1093/rfs/1.1.3

Aggarwal, R., \& Rivoli, P. (1989). Seasonal and Day-of-the-Week Effects in Four Emerging Stock Markets. Financial Review, 24(4), 541-550. http://dx.doi.org/10.1111/j.1540-6288.1989.tb00359.x

Agrawal, A., \& Tandon, K. (1994). Anomalies or Illusions? Evidence from Stock Markets in Eighteen Countries. Journal of international Money and Finance, 13(1), 83-106. http://dx.doi.org/10.1016/0261-5606(94)90026-4

Ajayi, R. A., Mehdian, S., \& Perry, M. J. (2004). The Day-of-the-Week Effect in Stock Returns: Further Evidence from Eastern European Emerging Markets. Emerging Markets Finance and Trade, 40(4), 53-62.

Arsad, Z., \& Andrew, C. J. (1997). Security Price Anomalies in the London International Stock Exchange: A 60 year perspective. Applied Financial Economics, 7(5), 455-464. http://dx.doi.org/10.1080/096031097333312

Badhani, K. (2006). Empirical Regularities in the Intra-Week Trading Patterns of Foreign Institutional Investors in India. Available at SSRN 900501.

Baker, R., \& Limmack, R. (1998). Firm Size, Monthly Seasonalities and Tax-loss Selling: Further Evidence from the UK. The British Accounting Review, 30(3), 221-248. http://dx.doi.org/10.1006/bare.1997.0067

Balaban, E. (1995). Day of the Week Effects: New Evidence from an Emerging Stock Market. Applied Economics Letters, 2(5), 139-143. http://dx.doi.org/10.1080/135048595357465

Balaban, E. (1996). Informational Efficiency of the Istanbul Securities Exchange and Some Rationale for Public Regulation. Institute of European Finance, University of North Wales.

Barry, C. B., \& Brown, S. J. (1984). Differential Information and the Small Firm Effect. Journal of Financial Economics, 13(2), 283-294. http://dx.doi.org/10.1016/0304-405X(84)90026-6

Bessembinder, H., \& Hertzel, M. G. (1993). Return autocorrelations around nontrading days. Review of Financial Studies, 6(1), 155-189. http://dx.doi.org/10.1093/rfs/6.1.155

Blau, B. M., Van Ness, B. F., \& Van Ness, R. A. (2009). Intraday Stealth Trading: Which Trades Move Prices During Periods of High Volume? Journal of Financial Research, 32(1), 1-21. http://dx.doi.org/10.1111/j.1475-6803.2008.01240.x

Brennan, M. J., \& Subrahmanyam, A. (1995). Investment Analysis and Price Formation in Securities Markets. Journal of Financial Economics, 38(3), 361-381. http://dx.doi.org/10.1016/0304-405X(94)00811-E

Brooks, C. (2014). Introductory Econometrics for Finance. London, UK: Cambridge University Press.

Brooks, C., \& Persand, G. (2001). Seasonality in Southeast Asian Stock Markets: Some New Evidence on $\begin{array}{lllll}\text { day-of-the-week } \quad \text { Effects. } & \text { Applied }\end{array}$ http://dx.doi.org/10.1080/13504850150504504

Brown, P., Keim, D. B., Kleidon, A. W., \& Marsh, T. A. (1983). Stock Return Seasonalities and the Tax-loss 
Selling Hypothesis: Analysis of the Arguments and Australian Evidence. Journal of Financial Economics, 12(1), 105-127. http://dx.doi.org/10.1016/0304-405X(83)90030-2

Brown, P., Kleidon, A. W., \& Marsh, T. A. (1983). New Evidence on the Nature of Size-related Anomalies in $\begin{array}{lllll}\text { Stock Prices. Journal of Financial } & \text { Economics, }\end{array}$ http://dx.doi.org/10.1016/0304-405X(83)90026-0

Chen, H., \& Singal, V. (2004). All Things Considered, Taxes Drive the January Effect. Journal of Financial Research, 27(3), 351-372. http://dx.doi.org/10.1111/j.1475-6803.2004.00095.x

Chen, Q., Jack, L., \& Wood, A. (2007). Tax-loss Selling and Seasonal Effects in the UK. Applied Financial Economics, 17(13), 1027-1035. http://dx.doi.org/10.1080/09603100600794317

Choudhry, T. (2001). Month of the year Effect and January Effect in pre-WWI Stock Returns: Evidence from a Non-linear GARCH Model. International Journal of Finance and Economics, 6(1), 1-11. http://dx.doi.org/10.1002/ijfe.142

Condoyanni, L., O'hanlon, J., \& Ward, C. W. (1987). Day of the week Effects on Stock Returns: International Evidence. Journal of Business Finance and Accounting, 14(2), 159-174. http://dx.doi.org/10.1111/j.1468-5957.1987.tb00536.x

Connolly, R. A. (1989). An Examination of the Robustness of the Weekend Effect. Journal of Financial and quantitative Analysis, 24(02), 133-169. http://dx.doi.org/10.2307/2330769

Constantinides, G. M. (1984). Optimal Stock Trading with Personal Taxes: Implications for Prices and the Abnormal January Returns. Journal of Financial Economics, 13(1), 65-89. http://dx.doi.org/10.1016/0304-405X(84)90032-1

Cross, F. (1973). The Behavior of Stock Prices on Fridays and Mondays. Financial Analysts Journal, 6(1), 67-69. http://dx.doi.org/10.2469/faj.v29.n6.67

Dicle, M., \& Hassan, M. (2007). Day of the week effect in Istanbul stock exchange. Scientific Journal of Administrative Development, 5(1), 1-27.

Draper, P., \& Paudyal, K. (1997). Microstructure and Seasonality in the UK Equity Market. Journal of Business Finance and Accounting, 24(7-8), 1177-1204. http://dx.doi.org/10.1111/1468-5957.00158

Dyl, E. A. (1977). Capital Gains Taxation and Year-end Stock Market Behavior. The Journal of Finance, 32(1), 165-175. http://dx.doi.org/10.1111/j.1540-6261.1977.tb03250.x

Elango, R., \& Al Macki, N. (2008). Monday effect and stock return seasonality: Further empirical evidence. The Business Review, 10(2), 282-288.

Foster, F. D., \& Viswanathan, S. (1990). A Theory of the Interday Variations in Volume, Variance, and Trading Costs in Securities Markets. Review of Financial Studies, 3(4), 593-624. http://dx.doi.org/10.1093/rfs/3.4.593

Fountas, S., \& Segredakis, K. N. (2002). Emerging Stock Markets Return Seasonalities: The January Effect and the tax-loss Selling Hypothesis. Applied Financial Economics, 12(4), 291-299. http://dx.doi.org/10.1080/09603100010000839

French, K. R. (1980). Stock Returns and the Weekend Effect. Journal of Financial Economics, 8(1), 55-69. http://dx.doi.org/10.1016/0304-405X(80)90021-5

French, K. R., \& Roll, R. (1986). Stock Return Variances: The Arrival of Information and the Reaction of Traders. Journal of Financial Economics, 17(1), 5-26. http://dx.doi.org/10.1016/0304-405X(86)90004-8

Friederich, S., Gregory, A., Matatko, J., \& Tonks, I. (2002). Short-run Returns around the Trades of Corporate Insiders on the London Stock Exchange. European Financial Management, 8(1), 7-30. http://dx.doi.org/10.1111/1468-036X.00174

Gibbons, M. R., \& Hess, P. (1981). Day of the Week Effects and Asset Returns. Journal of Business, 12(1), 579-596. http://dx.doi.org/10.1086/296147

Gregoriou, A., Kontonikas, A., \& Tsitsianis, N. (2004). Does the Day of the Week Effect Exist Once Transaction Costs have been Accounted for? Evidence from the UK. Applied Financial Economics, 14(3), 215-220. http://dx.doi.org/10.1080/0960310042000187388

Gregory, A., Matatko, J., Tonks, I., \& Purkis, R. (1994). UK Directors' Trading: The Impact of Dealings in Smaller Firms. The Economic Journal, 37-53. http://dx.doi.org/10.2307/2234673 
Gu, A. Y. (2003). The Declining January Effect: Experience of Five G7 Countries. International Journal of Finance, 15(1), 2465-2475.

Hansen, P., Lunde, A., \& Nason, J. (2005). Testing the significance of calendar effects. Federal Reserve Bank of Atlanta Working Paper (2005-02). http://dx.doi.org/10.2139/ssrn.388601

Hassouna, M., Tarhini, A., Elyas, T., \& AbouTrab, M. S. (2015). Customer Churn in Mobile Markets: A Comparison of Techniques. International Business Research, 8(6), 224-237. http://dx.doi.org/10.5539/ibr.v8n6p224

Haugen, R. A., \& Lakonishok, J. (1987). The Incredible January Effect: The Stock Market's Unsolved Mystery. Dow Jones-Irwin.

Henderson, Y. K. (1990). Capital Gains tax Rates and Stock Market Volume. National Tax Journal, 43(4), 411-425.

Hillier, D., \& Marshall, A. (2002a). Insider Trading, Tax-loss Selling, and the Turn-of-the-Year Effect. International Review of Financial Analysis, 11(1), 73-84. http://dx.doi.org/10.1016/S1057-5219(01)00065-5

Hillier, D., \& Marshall, A. P. (2002b). Are Trading Bans Effective? Exchange Regulation and Corporate Insider Transactions around Earnings Announcements. Journal of Corporate Finance, 8(4), 393-410. http://dx.doi.org/10.1016/S0929-1199(01)00046-3

Hussain, F., Hamid, K., Akash, R., \& Khan, M. (2011). Day of the week effect and stock returns: Evidence from Karachi stock exchange-Pakistan. Far East Journal of Psychology and Business, 3(1), 25-31.

Jaffe, J., \& Westerfield, R. (1985). Patterns in Japanese Common Stock Returns: Day of the Week and Turn of the Year Effects. Journal of Financial and Quantitative Analysis, 20(2), 261-272. http://dx.doi.org/10.2307/2330959

Jaffe, J., \& Westerfield, R. (1985). The Week-End Effect in Common Stock Returns: The International Evidence. The Journal of Finance, 40(2), 433-454. http://dx.doi.org/10.1111/j.1540-6261.1985.tb04966.x

Jain, P., \& Joh, G. H. (1988). The Dependence between Hourly Prices and Trading Volume. Journal of Financial and Quantitative Analysis, 23(3), 269-283. http://dx.doi.org/10.2307/2331067

Keim, D. B. (1983). Size-related Anomalies and Stock Return Seasonality: Further Empirical Evidence. Journal of Financial Economics, 12(1), 13-32. http://dx.doi.org/10.1016/0304-405X(83)90025-9

Keim, D. B., \& Stambaugh, R. F. (1984). A Further Investigation of the Weekend Effect in Stock Returns. The Journal of Finance, 39(3), 819-835. http://dx.doi.org/10.1111/j.1540-6261.1984.tb03675.x

Lakonishok, J., \& Maberly, E. (1990). The Weekend Effect: Trading Patterns of Individual and Institutional Investors. The Journal of Finance, 45(1), 231-243. http://dx.doi.org/10.1111/j.1540-6261.1990.tb05089.x

Lakonishok, J., \& Smidt, S. (1988). Are Seasonal Anomalies Real? A Ninety-Year Perspective. Review of Financial Studies, 1(4), 403-425. http://dx.doi.org/10.1093/rfs/1.4.403

Lakonishok, J., Shleifer, A., Thaler, R., \& Vishny, R. (1991). Window dressing by pension fund managers: National Bureau of Economic Research. NBER Working Paper.

Lim, S. Y., Mun Ho, C., \& Dollery, B. (2010). An Empirical Analysis of Calendar Anomalies in the Malaysian Stock Market. Applied Financial Economics, 20(3), 255-264. http://dx.doi.org/10.1080/09603100903282648

Martikainen, T., \& Puttonen, V. (1996). Finnish Day-of-the-Week Effects. Journal of Business Finance and Accounting, 23(7), 1019-1032. http://dx.doi.org/10.1111/j.1468-5957.1996.tb01038.x

Masa'deh, R., Tayeh, M., Al-Jarrah, I. M., \& Tarhini, A. (2015). Accounting vs. Market-based measures of firm performance related to information technology investments. International Review of Social Sciences and Humanities, 9(1), 129-145.

Masa'deh, R., Obeidat, B. Y., Al-Dmour, R. H., \& Tarhini, A. (2015). Knowledge management strategies as intermediary variables between IT-business strategic alignment and firm performance. European Scientific Journal, 11(7), 344-368.

Masa'deh, R., Tarhini, A., Al-Dmour, R. H., \& Obeidat, B. Y. (2015). Strategic IT-business alignment as managers' explorative and exploitative strategies. European Scientific Journal, 11(7), 437-457.

Mehdian, S., \& Perry, M. J. (2001). The Reversal of the Monday Effect: New Evidence from US Equity Markets. 
Journal of Business Finance and Accounting, 28(7-8), 1043-1065. http://dx.doi.org/10.1111/1468-5957.00404

Mehdian, S., \& Perry, M. J. (2002). Anomalies in US Equity Markets: A Re-Examination of the January Effect. Applied Financial Economics, 12(2), 141-145. http://dx.doi.org/10.1080/09603100110088067

Meier, I., \& Schaumburg, E. (2004). Do Funds Window Dress? Evidence for US Domestic Equity Mutual Funds. Unpublished working paper, HEC Montreal and Kellogg School of Management.

Musto, D. K. (1997). Portfolio Disclosures and Year-End Price Shifts. The Journal of Finance, 52(4), 1563-1588. http://dx.doi.org/10.1111/j.1540-6261.1997.tb01121.x

Nath, G. C., \& Dalvi, M. (2004). Day of the Week Effect and Market Efficiency-Evidence from Indian Equity Market using High Frequency Data of National Stock Exchange. http://dx.doi.org/10.2139/ssrn.1092765

Osborne, M. (1962). Periodic Structure in the Brownian Motion of Stock Prices. Operations Research, 10(3), 345-379. http://dx.doi.org/10.1287/opre.10.3.345

Orozco, J., Tarhini, A., Masa'deh, R., \& Tarhini, T. (2015). A framework of IS/business alignment management practices to improve the design of IT Governance architectures. International Journal of Business and Management, 10(4), 1-12. http://dx.doi.org/10.5539/ijbm.v10n4p1

Orozco, J., El-Masri, M., Tarhini, A., \& Tarhini, T. (2015). The Impact of IS-Business Alignment Practices on Organizational Choice of IS-Business Alignment Strategies. The 19th Pacific Asia Conference on Information Systems (PACIS 2015), Singapore, 6-9 July 2015.

Penman, S. H. (1987). The Distribution of Earnings News Over Time and Seasonalities in Aggregate Stock Returns. Journal of Financial $\quad$ Economics, $\quad 18(2), \quad$ 199-228. http://dx.doi.org/10.1016/0304-405X(87)90039-0

Reinganum, M. R. (1983). The Anomalous Stock Market Behavior of Small Firms in January: Empirical Tests for Tax-Loss Selling Effects. Journal of Financial Economics, 12(1), 89-104. http://dx.doi.org/10.1016/0304-405X(83)90029-6

Reinganum, M. R., \& Shapiro, A. C. (1987). Taxes and Stock Return Seasonality: Evidence from the London Stock Exchange. Journal of Business, 281-295. http://dx.doi.org/10.1086/296396

Ritter, J. R., \& Chopra, N. (1989), Portfolio Rebalancing and the Turn-of-the-Year Effect. The Journal of Finance, 44(1), 149-166. http://dx.doi.org/10.1111/j.1540-6261.1989.tb02409.x

Roll, R. (1983). On Computing Mean Returns and the Small Firm Premium. Journal of Financial Economics, 12(3), 371-386. http://dx.doi.org/10.1016/0304-405X(83)90055-7

Rozeff, M. S., \& Kinney, Jr. W. R. (1976). Capital Market Seasonality: The Case of Stock Returns. Journal of Financial Economics, 3(4), 379-402. http://dx.doi.org/10.1016/0304-405X(76)90028-3

Rystrom, D. S., \& Benson, E. D. (1989). Investor Psychology and the Day-of-the-Week Effect. Financial Analysts Journal, 45(5), 75-78. http://dx.doi.org/10.2469/faj.v45.n5.75

Seyhun, H. N. (1988a). The Information Content of Aggregate Insider Trading. Journal of Business, 61(1), 1-24. http://dx.doi.org/10.1086/296417

Seyhun, H. N. (1988b). The January Effect and Aggregate Insider Trading. The Journal of Finance, 43(1), 129-141. http://dx.doi.org/10.1111/j.1540-6261.1988.tb02593.x

Sias, R. W., \& Starks, L. T. (1995). The Day-of-the-Week Anomaly: The Role of Institutional Investors. Financial Analysts Journal, 58-67. http://dx.doi.org/10.2469/faj.v51.n3.1906

Siegel, J. J. (1998). Stocks for the Long Run by Jeremy Siegel. NewYork, USA.

Solnik, B., \& Bousquet, L. (1990). Day-of-the-Week Effect on the Paris Bourse. Journal of Banking and Finance, 14(2), 461-468. http://dx.doi.org/10.1016/0378-4266(90)90059-B

Sullivan, R., Timmermann, A., \& White, H. (2001). Dangers of data mining: The case of calendar effects in stock returns. Journal of Econometrics, 105(1), 249-286. http://dx.doi.org/10.1016/S0304-4076(01)00077-X

Wong, M. C., Cheung, Y. L., \& Wu, L. (2000). Insider Trading in the Hong Kong Stock Market. Asia-Pacific Financial Markets, 7(3), 275-288. http://dx.doi.org/10.1023/A:1010009016980 


\section{Copyrights}

Copyright for this article is retained by the author(s), with first publication rights granted to the journal.

This is an open-access article distributed under the terms and conditions of the Creative Commons Attribution license (http://creativecommons.org/licenses/by/3.0/). 